\title{
Flora do Parque Nacional do Itatiaia - Brasil: Peperomia (Piperaceae) ${ }^{1}$
}

Daniele Monteiro $^{2}$ \& Elsie Franklin Guimarães ${ }^{3}$

\section{Resumo}

(Flora do Parque Nacional do Itatiaia - Brasil: Peperomia (Piperaceae)) O Parque Nacional do Itatiaia tem sido objeto de estudo mesmo antes de ser designado como parque em junho de 1937. Localizado em terras fluminenses e mineiras, protege atualmente cerca de 30.000 hectares de patrimônio biótico e geomorfológico da Serra da Mantiqueira. A pesquisa teve como objetivo conhecer e descrever os táxons de Peperomia ocorrentes na região, averiguando suas preferências ambientais, além de ampliar o conhecimento sobre espécies raras e endêmicas e gerar subsídios para o conhecimento da flora do estado. Peperomia, o segundo maior gênero das Piperaceae, apresenta cerca de 1.500 espécies, das quais aproximadamente 200 ocorrem no Brasil, habitando preferencialmente locais úmidos e sombreados. O levantamento realizado levou ao reconhecimento de 34 taxa, dos quais seis constituíram novas ocorrências para a região. Estes táxons, que ocorrem no interior da floresta e nos campos de altitude, são encontrados em gradientes altitudinais de 600 a $2.700 \mathrm{~m}$, como epífitos, saxícolos ou terrestres e são diferenciados principalmente pela filotaxia, forma, tamanho e nervação foliares, pilosidade, comprimento do pecíolo e pedúnculo e forma dos frutos.

Palavras-chave: campos de altitude, florística, floresta atlântica, taxonomia, Unidade de Conservação.

\section{Abstract}

(Flora of the Itatiaia National Park - Brazil: Peperomia (Piperaceae)) Itatiaia National Park has been studied since before being recognized as a conservation area, in June of 1937. With its area located between the states of Rio de Janeiro and Minas Gerais, it currently protects approximately 30,000 hectares of biotic and geomorphological heritage of the Serra da Mantiqueira. This research aims to describe the taxa of Peperomia found in the park, including their preferred habitat, highlighting rare and endemic species and contributing to the flora of state Rio de Janeiro. Peperomia, the second largest genus of the Piperaceae, has about 1500 species, with 200 Brazilian representatives ocurring especially in humid and shady habitats. This study detected 34 taxa, six of them being new occurrences for the area. These taxa, that occur in forest shade and in the "campos de altitude", are found in altitudinal gradients from 600-2700 m, as epiphytes, saxicolous or terricolous plants and are distinguished mainly by phylotaxy, form, size and venation of the leaf, indumentum, petiole and peduncle length and fruit shape. Key words: 'campos de altitude', floristic, atlantic forest, taxonomy, Unit of Conservation.

\section{INTRODUÇÃO}

O Parque Nacional do Itatiaia foi a primeira Unidade de Conservação criada no Brasil, em 14 de junho de 1937, protege atualmente cerca de 30.000 hectares de patrimônio biótico e geomorfológico na Serra da Mantiqueira, sendo coberto por floresta ombrófila densa montana e alto-montana em vários estágios de conservação,além de campos de altitude (sensu Velloso et al. 1991). O Parque fica localizado ao sul do estado do Rio de

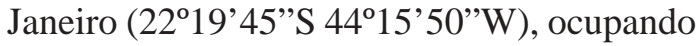
terras fluminenses, em sua maior parte (municípios de Itatiaia e Resende) e mineiras (municípios de Itamonte, Alagoa e Bocaina de Minas), estendendo-se a oeste, próximo à divisa com São Paulo (Brade 1956; www.ibama.gov.br/parna_itatiaia). Mesmo antes de receber o título de Parque Nacional, a região foi explorada por vários pesquisadores como Saint Hilaire, Sellow e Glaziou no século XVIII e por Hemmendorff e Dusén no início do século XIX, que analisaram o aspecto fitofisionômico e a constituição da flora da região, formada por floresta ombrófila densa e campos de altitude (Dusén 1905; Martinelli 1989). Mais recentemente Brade (1956), Barros (1955) e Ribeiro \& Medina (2002)

Artigo recebido em 08/2007. Aceito para publicação em 12/2007.

${ }^{1}$ Parte da dissertação de mestrado da primeira autora, desenvolvida na Escola Nacional de Botânica Tropical / JBRJ. ${ }^{2}$ Bolsista CAPES. Pacheco Leão 2040, Solar da Imperatriz, 22460-030, Rio de Janeiro, RJ, Brasil. daniele @ jbrj.gov.br ${ }^{3}$ Bolsista do CNPq; Pesquisadora do Instituto de Pesquisas Jardim Botânico do Rio de Janeiro/Programa Mata Atlântica. Rua Pacheco Leão 915, 22460-030, Rio de Janeiro, RJ, Brasil. eguimar@jbrj.gov.br 
estudaram a constituição da flora com relação à altitude, as diferenças ecológicas dos lados oriental e ocidental da serra e os padrões biogeográficos da vegetação.

Piperaceae é uma das maiores famílias dentre as angiospermas basais, somando aproximadamente 3.000 espécies (Bornstein 1989) de distribuição pantropical e centro de diversidade nas Américas Central e do Sul e na Malásia (Yuncker 1958). As suas espécies apresentam-se como ervas, subarbustos, arbustos ou lianas, geralmente aromáticas e dotadas de glândulas translúcidas, com tipo de indumento variado. As folhas são alternas, opostas ou verticiladas, simples e inteiras, de forma consistência, tamanho e padrão de nervação diversos, geralmente com profilos. As flores são aclamídeas, mínimas, andróginas, protegidas por uma bractéola de forma variada, dispostas esparsa ou densamente em racemos, espigas ou umbelas de espigas, eretas ou curvas, com estames geralmente 2-6, anteras bitecas de deiscência rimosa, gineceu mono, tri ou tetracarpelar, síncárpico, unilocular, uniovular, com 1-4 estigmas, sendo o fruto uma baga de forma variada.

Peperomia tem cerca de 1.500 espécies, diversamente distribuídas no neotrópico (Wanke et al. 2006), sendo algumas cultivadas como ornamentais, outras usadas no tratamento de doenças, como $P$. alata e $P$. glabella que possuem ação antimalárica (Milliken 1997) e $P$. rotundifolia - estomáquica, além de $P$. pellucida empregada na culinária (Lorenzi \& Matos 2002). Dos cinco gêneros hoje considerados para a família, Macropiper, Zippelia, Piper, Peperomia e Manekia (Jaramillo et al. 2004), os três últimos ocorrem no Brasil principalmente nas florestas Atlântica e Amazônica e são também encontrados no Parna do Itatiaia. A escolha de Peperomia para iniciar o estudo florístico da família na região se deve aos poucos exemplares do gênero, pequenos e geralmente epífitos, encontrados nos herbários e por ser este de grande representatividade no estrado epifítico-herbáceo da Mata Atlântica. O trabalho com os táxons de Piper e Manekia ocorrentes na região, está sendo realizado e será em breve divulgado.
Esta pesquisa teve como objetivos estudar as espécies de Peperomia ocorrentes no Parna do Itatiaia, detectar espécies endêmicas e raras, resgatar informações e promover o conhecimento da flora da região, auxiliando no monitoramento da Unidade de Conservação, além de ampliar o conhecimento da flora dos estados do Rio de Janeiro e de Minas Gerais.

\section{Material e Métodos}

O material botânico foi obtido de coletas realizadas entre os anos de 2004 e 2006 e do levantamento de exemplares preservados em herbários nacionais e internacionais. Materiais-tipo e de outras localidades foram analisados quando necessário. As descrições foram feitas com base na análise da morfologia externa dos exemplares, com o auxílio de microscópio estereoscópico. Foram priorizados para as ilustrações táxons pouco ilustrados e conhecidos, e os que representaram uma nova ocorrência para o do Rio de Janeiro. Para descrição da forma e padrões de nervação das folhas foram utilizados Hickey (1974) e Rizzini (1960) e para a descrição dos tipos de tricomas Hickey \& King (2003). A etimologia foi feita com base em Rizzini (1978) e Rizzini \& Rizzini (1983). A distribuição geográfica foi retirada das informações encontradas nas bibliografias e ampliada com as consultas aos herbários.

As espécies são apresentadas em ordem alfabética contendo a distribuição geográfica, habitat, lista das exsicatas examinadas e comentários. Em táxons mais coletados a lista do material citado foi selecionada, sendo considerado um de cada localidade da área de estudo. Todos os espécimes estudados são apresentados no índice de coletores.

\section{Resultados e Discussão}

Peperomia Ruiz \& Pav., Prodr. Fl. Peruv. 8. 1794.

As espécies de Peperomia são ervas anuais ou perenes, terrestres, epífitas ou rupícolas, freqüentemente carnosas, com folhas alternas, opostas ou verticiladas; inflorescências em racemos ou espigas 
terminais, axilares ou opostas às folhas com flores diminutas, protegidas por uma bractéola, ovário unicarpelar e estames dois, dispostos lateralmente, na base do pistilo e frutos com ápice pontuado, mamiliforme, rostrado ou com escudo oblíquo, por vezes com pseudo-cúpula na base.

No Parque Nacional do Itatiaia foram encontrados 34 taxa, dos quais 31 estão distribuídos na floresta ombrófila densa e três nos campos de altitude. Cinco espécies e uma variedade ainda não haviam sido registradas para a região: $P$. catharinae, $P$. glabela var. nigropunctata, $P$. mandioccana, $P$. ouabianae, $P$. rubricaulis e $P$. trinervis, o que ressalta a importância de inventários florísticos. A maioria das taxas estudadas são conhecidas popularmente como erva-de-jaboti, jaboti-membeca, erva-de-vidro (Guimarães et al. 1984), entretanto, Burger (1971) considera o nome língua-de-sapo para $P$. galioides, carrapatinho ou salva-vidas para $P$. rotundifolia e corredera, garrapatilha ou hilotillo para P. tetraphylla var. tetraphylla. Para as outras espécies não foi encontrada denominação popular.

\section{Chave de identificação para os táxons}

1. Folhas alternas.

2. Planta glabra (por vezes com linha de tricomas no pecíolo ou ápice da lâmina cerdoso ou ciliado).

3. Ramos alados

1. P. alata

3'. Ramos não alados.

4. Pecíolo de $8-15 \mathrm{~cm}$ compr.; base da lâmina foliar cordada, às vezes peltada ... 2. P. arifolia

4'. Pecíolo até $1,3 \mathrm{~cm}$ compr.; base da lâmina foliar aguda a obtusa, não peltada

5. Lâmina foliar com ápice emarginado 17. P. martiana

5'. Lâmina foliar com ápice não emarginado.

6. Pecíolo com linha de tricomas

11. P. glabella var. glabella

6'. Pecíolo sem linha de tricomas.

7. Lâmina foliar rômbico-lanceolada, elíptico-lanceolada; padrão de nervação misto camptódromo-acródromo supra-basal

7'. Lâmina foliar ovada, ovado-elíptica, ovado-lanceolada, rômbicoovada, ovado-oblonga, lanceolada a lanceolado-oblonga; padrão de nervação misto camptódromo-acródromo basal.

8. Lâmina foliar densamente negro-gladulosa, ápice glabro ....... 11a. P. glabella var. nigropunctata 8'. Lâmina foliar esparsamente castanho-glandulosa, ápice cerdoso.

9. Folhas translúcidas; margem da lâmina ciliada acima da porção mediana até o ápice; fruto $0,5-1 \mathrm{~mm}$ compr....... 9. P. diaphanoides

9'. Folhas não translúcidas, margem da lâmina eciliada, ápice cerdoso; fruto ca. $1,5 \mathrm{~mm}$ compr. 3. P. augescens

2'. Planta com tricomas.

10. Inflorescência em racemo.

11. Lâmina foliar com tricomas em ambas as faces

11'. Lâmina foliar glabra em ambas as faces 25. P. tenella 10'. Inflorescência em espiga. 
12. Lâmina foliar glabra em ambas as faces.

13. Folhas alternas na base, opostas ou ternadas no ápice; lâmina $1,3-2,3 \mathrm{~cm}$ compr. ...

16. P. mandioccana

13'. Folhas alternas da base ao ápice; lâmina 3,5-5 cm compr.

13. P. hilariana

12'. Lâmina foliar com tricomas em uma ou em ambas as faces.

14. Base da lâmina foliar arredondada a cordada; fruto com ápice rostrado

30. P. urocarpa

14'. Base da lâmina foliar não cordada; fruto com ápice não rostrado.

15. Fruto com pseudocúpula basal; estigma apical.

16. Pedúnculo $1,4-1,8 \mathrm{~cm}$ compr.

7. P. corcovadensis

16'. Pedúnculo 0,4-1,2 cm compr.

17. Lâmina foliar de duas a três vezes mais longas do que largas; espigas $0,6-2 \mathrm{~cm}$ compr.

20. P. pseudoestrellensis

17 '. Lâmina foliar duas vezes mais longas do que largas; espigas $2,5-3,5 \mathrm{~cm}$ compr.

6. P. clivicola

$15^{\prime}$. Fruto sem pseudocúpula basal; estigma subapical.

18. Espigas 1,2-1,7 cm compr.; presença de bráctea peducular

22. $P$. rotundifolia

18'. Espigas 2-6,5 cm compr.; ausência de bráctea peduncular.

19. Lâmina foliar $0,7-1,2 \mathrm{~cm}$ compr.; espigas $2-3 \mathrm{~cm}$ compr.

19. P. ouabianae

19'. Lâmina foliar 3-5 cm compr.; espigas 4-6,5 cm compr.

20. Pedúnculo $0,7-1 \mathrm{~cm}$ compr.

27. P. trinervis

20’. Pedúnculo 1,5-3 cm compr.

15. P. itatiaiana

1 '. Folhas opostas ou verticiladas.

21. Folhas opostas.

22. Ramos quadrangulares, com sulcos profundos quando seco; espigas até $2,5 \mathrm{~cm}$ compr.

12. P. glazioui

22'. Ramos cilíndricos, ligeiramente sulcados quando secos; espigas com $3 \mathrm{~cm}$ compr. ou mais.

23. Ramos hirtelos; forma da lâmina foliar igual da base ao ápice; fruto com pseudocúpula basal.

24. Lâmina obovada a elíptico-obovada, ápice obtuso a arredondado, emarginado

24. P. subternifolia

24'. Lâmina ovada a ovado-elíptica, ápice agudo, não emarginado

16. P. mandioccana

23 '.Ramos vilosos; forma da lâmina foliar da base diferente das do ápice; fruto sem pseudocúpula basal

4. P. blanda

21'. Folhas verticiladas.

25. Lâmina até $2,5 \mathrm{~cm}$ compr.

26. Ramos com tricomas vilosos

8. P. crinicaulis

26'. Ramos com tricomas hirtos, hirtelos ou glabrescentes.

27. Lâmina com ápice emarginado.

28. Lâmina $0,5-0,7 \mathrm{~cm}$ larg.

21. P. quadrifolia

28'.Lâmina $0,8-1,9 \mathrm{~cm}$ larg.

24. P. subternifolia

27'. Lâmina com ápice não emarginado.

29. Espigas até $2,5 \mathrm{~cm}$ compr.

30.Folhas 3-verticiladas com lâmina elíptica, elíptico-obovada; pedúnculo com tricomas mais longos que o dos ramos

5. P. catharinae 
30'.Folhas 4-verticiladas com lâmina ovada, rômbico-ovada, rômbicoelíptica; pedúnculo com tricomas do mesmo tamanho que o dos ramos 26. P. tetraphylla var.

29'. Espigas além de 2,5 cm compr.

31. Folhas alternas na base, opostas a ocasionalmente 3-4 verticiladas no ápice dos ramos 16. P. mandioccana 31 '.Folhas $3-8$ verticiladas.

32. Lâmina oblonga, oblongo-lanceolada; fruto com estigma subapical 10. P. galioides 32'.Lâmina rômbico-lanceolada a rômbico-obovada; fruto com estigma apical 33.Lâmina foliar 0,3-0,6 cm larg.; espigas 5-9,5 cm compr.

28. P. trineura

33'.Lâmina foliar $0,8-1,5 \mathrm{~cm}$ larg.; espigas 7-14 cm compr. 29. P. trineuroides

25'. Lâmina além de 2,5 cm compr.

34. Ramos e lâmina com tricomas; folhas opostas ou 3-verticiladas, as da base diferentes das do ápice 4. P. blanda

34'. Ramos e lâmina glabros; folhas 3-5 verticiladas, as da base iguais as do ápice. 35.Lâmina crassa a coriácea, margem revoluta; pedúnculo $2-5 \mathrm{~cm}$ compr., glabro 23. $P$. rubricaulis 35'.Lâmina cartácea a membranácea, margem plana; pedúnculo 1-2 cm compr., hirtelo 18. P. megapotamica

1. Peperomia alata Ruiz \& Pav., Fl. Peruv. 1: 31, tab. 48, fig b. 1798. Fig. 1a-d.

Erva ca. $30 \mathrm{~cm}$ alt., epífita ou rupícola, semi ciófila, glabra; ramos decumbentes, alados, suculentos, glandulosos. Folhas alternas; pecíolo $0,5-1 \mathrm{~cm}$ compr., canaliculado; lâmina 5-8(-11) ×2-4,2 cm, lanceolada, elípticolanceolada, ovado-lanceolada, base aguda, ápice acuminado ciliado, cartácea, discolor, nítida na face adaxial, castanho-glandulosa na abaxial, margem plana; padrão de nervação misto, acródromo basal, broquidódromo; nervuras 3-5. Espigas 7-3 $(-20) \times 0,1 \mathrm{~cm}$, axilares, ou terminais, solitárias, prostadas na lâmina, verde-claras; pedúnculo 0,5-1,5 (-2) cm compr.; raque foveolada, lisa; flores dispostas de forma pouco densa; bractéola arredondadopeltada, glandulosa, glabra de margem inteira. Fruto ca. $1 \mathrm{~mm}$ compr., globoso-ovóide, ápice com escudo oblíquo, glanduloso, marromacastanhado, pouco imerso na raque; estigma subapical.

Distribuição geográfica e habitat: Antilhas, Cuba, América Central, Colômbia, Venezuela, Guianas, Suriname, Equador, Peru e Bolívia. No
Brasil ocorre em Roraima, Amazonas, Distrito Federal, Goiás, Paraná, Santa Catarina e em todos os estados da Região Sudeste. No Rio de Janeiro é encontrada em remanescentes florestais. No Parna do Itatiaia ocorre de forma pouco frequente na floresta ombrófila densa montana e alto-montana, em altitudes que variam de $600-1.100 \mathrm{~m}$.

Material selecionado: caminho para o Véu de Noiva, 1.100 ms.m., 12.X.1977, fl., G. Martinelli \& P. Maas 3250 (RB); picada Macieiras, matas secundárias, 1.050-1.250 ms.m., 30.IV.1985, fl. e fr., G. Martinelli et al. 10748 (RB, SI e US n.v.); trilha do Hotel Simon para os Três Picos, 1.100 ms.m., 22 $2^{\circ} 15^{\prime}$ '28"S 44 34' 45"W, 14.II.1995, fl. e fr., J.M.A. Braga et al. 2002 (RB); ponte do Maromba, próximo do estacionamento, margem do rio Campo Belo, $22^{\circ} 15^{\prime} 28^{\prime \prime S} 44^{\circ} 34^{\prime}$ 45"W, 1.050 ms.m., 28.III.1995, fl. e fr., J.M.A. Braga et al. 2285 (RB, F, GUA, HUAe RUSU n.v.); encosta a direita (descendo) do rio Taquaral, $22^{\circ} 15^{\prime} 28^{\prime \prime S}$ 44 34' 45"W, 660-720 ms.m., 31.V.1995, fl., J. M. A. Braga et al. 2421 (RB, HUAe RUSU n.v.); próximo ao rio que fica ao lado do alojamento III, 4.VI.2005, fl. e fr., D. Monteiro \& G. Santos 113 (BHCB, RB); trilha para a cachoeira Poranga, 6.VI.2005, fl., $D$. Monteiro \& G. Santos 138 (RB, S). 


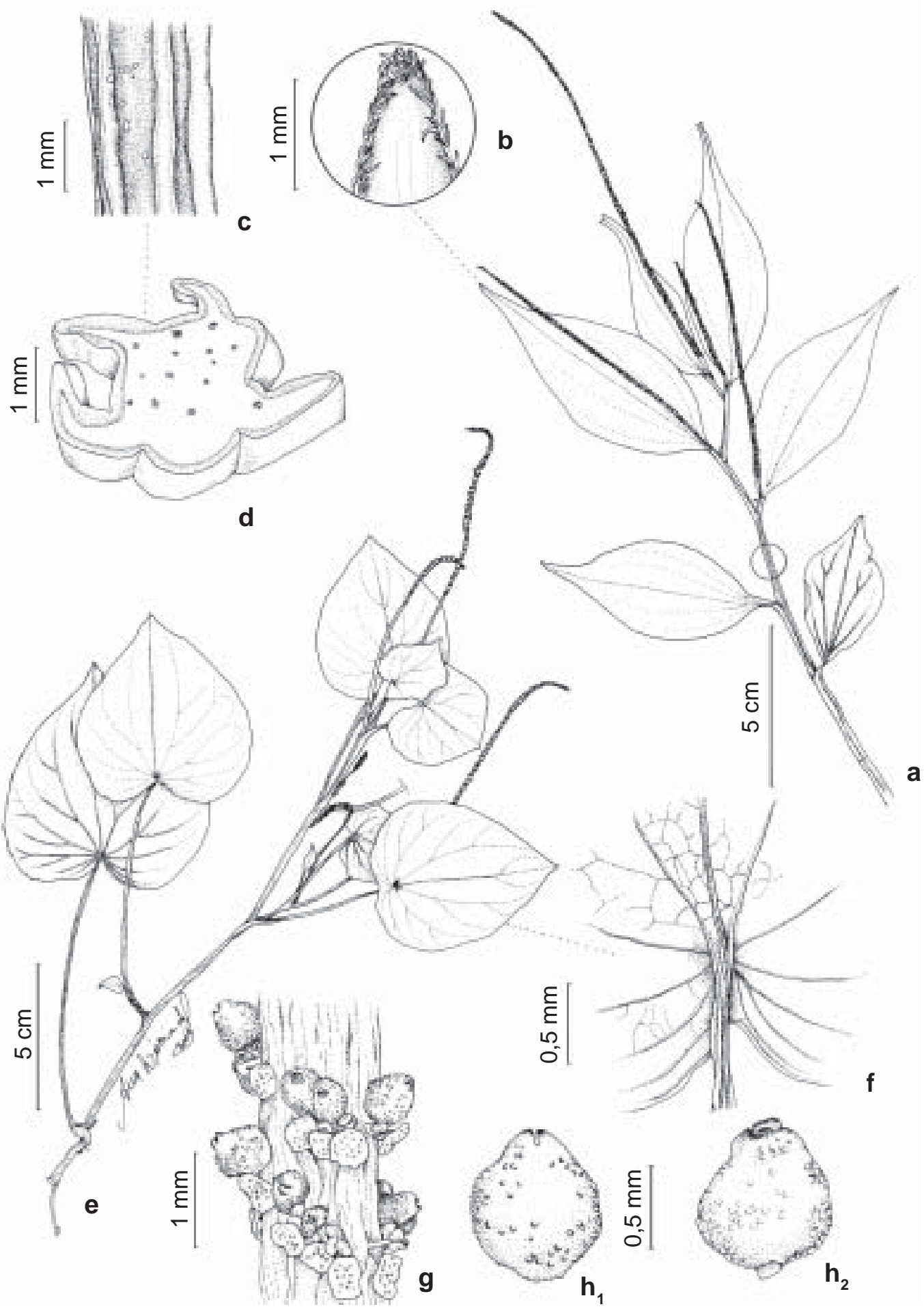

Figura 1 - a-d. Peperomia alata Ruiz \& Pav. - a. hábito; b. ápice da lâmina ciliado; c. parte do ramo alado; d. ramo alado em corte transversal. e-h. P. arifolia Miq. - e. hábito; f. lâmina peltada em detalhe; g. espiga em frutificação; $\mathrm{h}_{1}$. fruto em visão anterior, mostrando o estigma apical fendido; $h_{2}$. fruto em visão posterior. (a-d Braga 2938; e-f Monteiro 90; g-h Braga 1560). 
Os ramos alados e decumbentes, folhas grandes, lanceoladas, elíptico-lanceoladas a ovado-lanceoladas, tornam fácil o reconhecimento de Peperomia alata no campo. Em material seco, por vezes, a visualização da ala do caule é dificultada, o que se resolve com a fervura de parte do ramo. O comprimento das espigas nos espécimes da região é maior do que o encontrado por Ichaso \& Guimarães (1984) e Yuncker (1974). Burger (1971) considera por vezes a ocorrência de folhas opostas, o que não foi observado nos espécimes brasileiros, bem como um pseudopedicelo nos fruto em estágios mais avançados. O nome do táxon vem do latim alatus, em referência ao caule alado. Floresce e frutifica de novembro a junho.

\section{Peperomia arifolia Miq., Syst. Piperac.} 1: 72.1843 .

Fig. 1e-h

Erva $24-50 \mathrm{~cm}$ alt., terrestre ou rupícola, umbrófila, glabra; ramos eretos, cilíndricos, carnosos, não alados, vináceos, sulcados quando secos. Folhas alternas; pecíolo $8-15 \mathrm{~cm}$ compr., canaliculado; lâmina 7-12×4,5-9,5 cm, ovada, base cordada, com sinos abertos ou fechados, às vezes peltada, ápice obtuso à agudo, cartácea à translúcido-membranácea, discolor, moderada a densamente castanho-glandulosa na face adaxial, margem plana, eciliada; padrão de nervação misto, campilódromo-broquidódromo; nervuras 9-11, ascendentes. Espigas 5-12 $\times$ $0,2-0,3 \mathrm{~cm}$, axilares ou terminais, solitárias, flexuosas, brancas quando jovens; pedúnculo 7-10 cm compr., vináceo; raque foveolada, lisa; flores densamente dispostas; bractéola ovadoarredondado, peltada, com numerosas glândulas castanhas, glabra, de margem inteira. Fruto ca. $1 \mathrm{~mm}$ compr., globoso, ápice mamiliforme, castanho-avermelhado, pouco imerso na raque, papiloso; estigma apical, por vezes fendido.

Distribuição geográfica e habitat: Bolívia, Paraguai e Argentina. No Brasil, em Goiás, Bahia, Mato Grosso, Mato Grosso do Sul, Distrito Federal e todos os estados das Regiões Sudeste e Sul. No Parna do Itatiaia é encontrada na floresta ombrófila densa montana.
Material selecionado: lote 28, 5.II.1948, fl., A. C. Brade 18827 (RB); próximo Registro, 14.XI.1954, fl., A. C. Brade \& Pabst s.n. (HB-10277); ponte do Maromba, proximidade das margens do rio Campo Belo, 22 ${ }^{\circ} 15^{\prime} 28^{\prime \prime S} 44^{\circ} 34^{\prime} 45^{\prime \prime} \mathrm{W}, 1.100$ ms.m., 4.XII.1996, fl. e fr., J. M. A. Braga et al. 3725 (RB); trilha para a cachoeira Véu de Noiva, 1.200 ms.m., 10.VIII.2004, fl., D. Monteiro et al. 62 (RB); trilha em direção a cachoeira do Itaporoni, 2.XII.2006, fl. e fr., D. Monteiro \& A. C. Giannerine 209 (RB); trilha para os Três Picos, próximo ao primeiro córrego, 3.XII.2006, fl. e fr., D. Monteiro \& A. C. Giannerine 231 (RB, S).

Peperomia arifolia caracteriza-se pelas folhas grandes e cordadas, nítidas na face adaxial e as espigas longas e brancas, o que torna a planta bastante ornamental, como já citado por Corrêa (1984). O exemplar Brade 18827 estava depositado no herbário RB como Peperomia gardneriana Miq. e foi citado por Yuncker (1974) como $P$. serpentarioides Miq.; o material na verdade é $P$. arifolia, que difere das espécies supramencionadas principalmente por estas apresentarem o fruto sulcado e as folhas não peltadas de ápice agudo-acuminado, respectivamente. Ichaso \& Guimarães (1984) observaram a presença de papilas agudas na face ventral da lâmina foliar o que a torna levemente escabra, além de serem as flores dispostas subhelicoidalmente; o pedúnculo também é de tamanho um pouco maior nos materiais analisados pelas autoras. O nome do táxon vem do latim arum (anel) e folium (folha), em referência à forma das folhas ovado-cordadas. Floresce e frutifica de agosto a fevereiro.

3. Peperomia augescens Miq., Arch. Neerl. Sci. Exact. Nat., 6: 171. 1871. Fig. 2a-b

Erva $14-25 \mathrm{~cm}$ alt., estolonífera, rupícola ou terrestre, umbrófila ou semi-ciófila, glabra; ramos eretos ou ascendentes, cilíndricos, suculentos, não alados, vináceos, sulcados quando secos, glabros. Folhas alternas; pecíolo 0,6-1 cm compr., canaliculado, sem linha de tricomas; lâmina 2,5-6,5× 1,5-3 cm, rômbicoovada, ovada, ovado-oblonga, lanceolada, 


\section{ह}
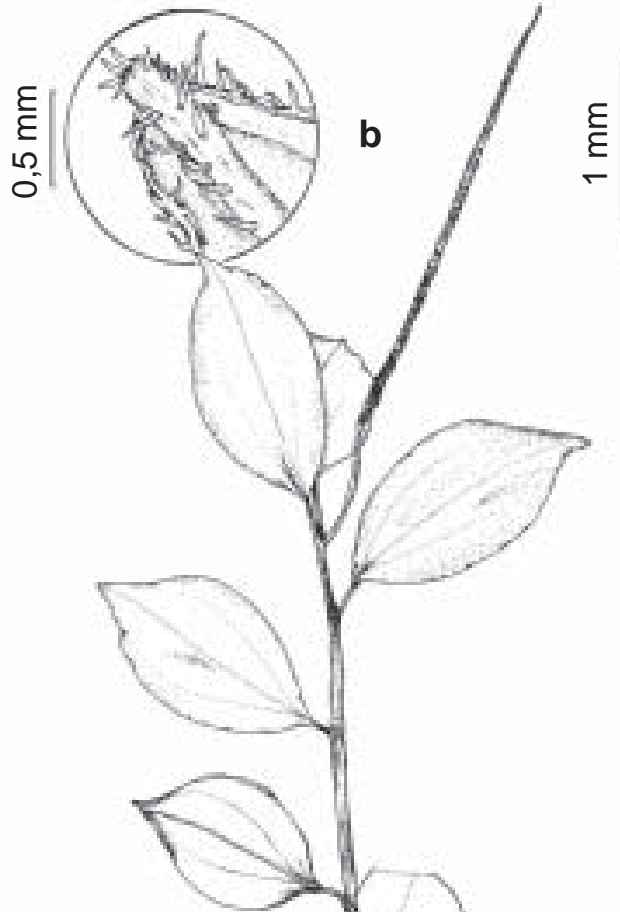

.
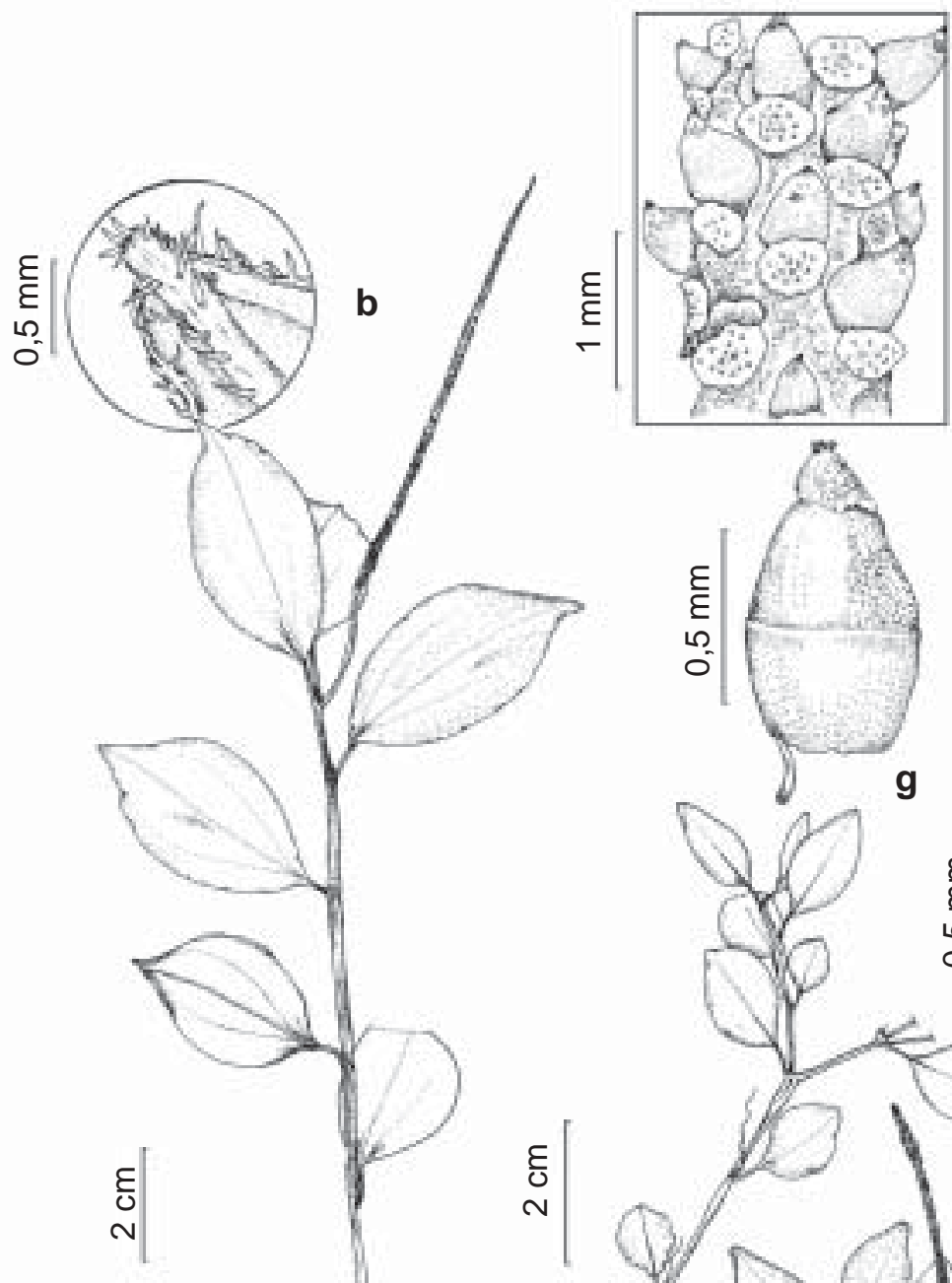

(n)

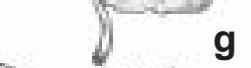

g
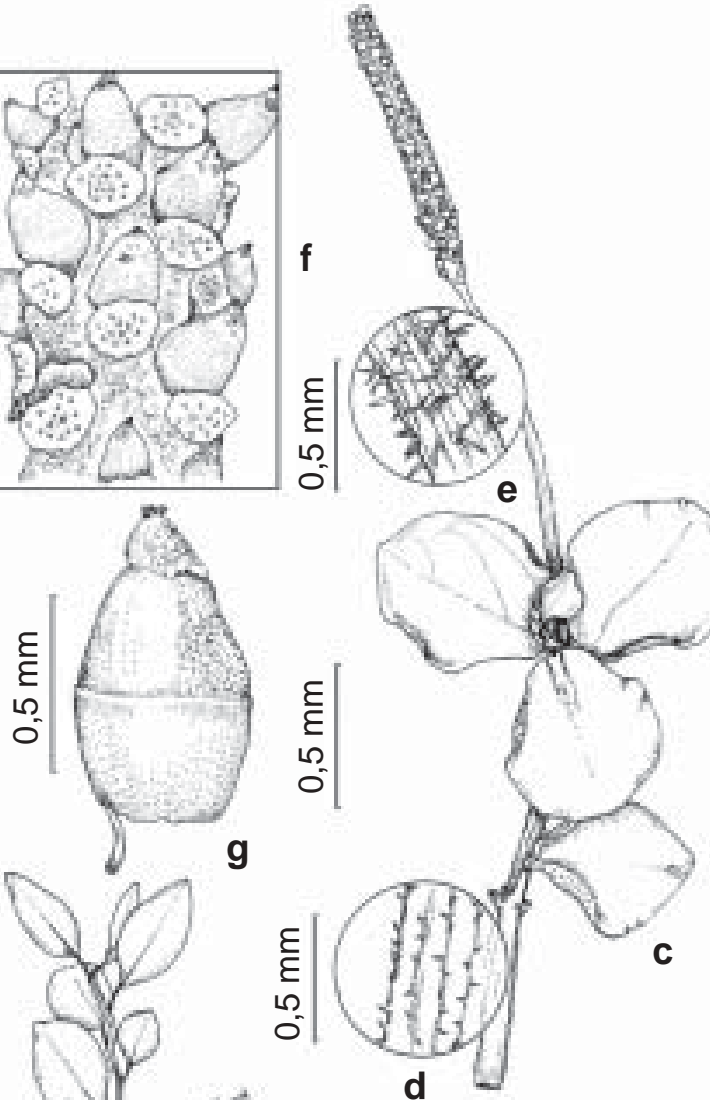

$\mathbf{f}$

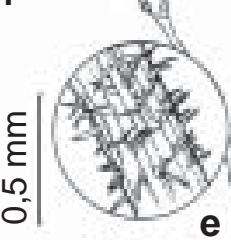

e
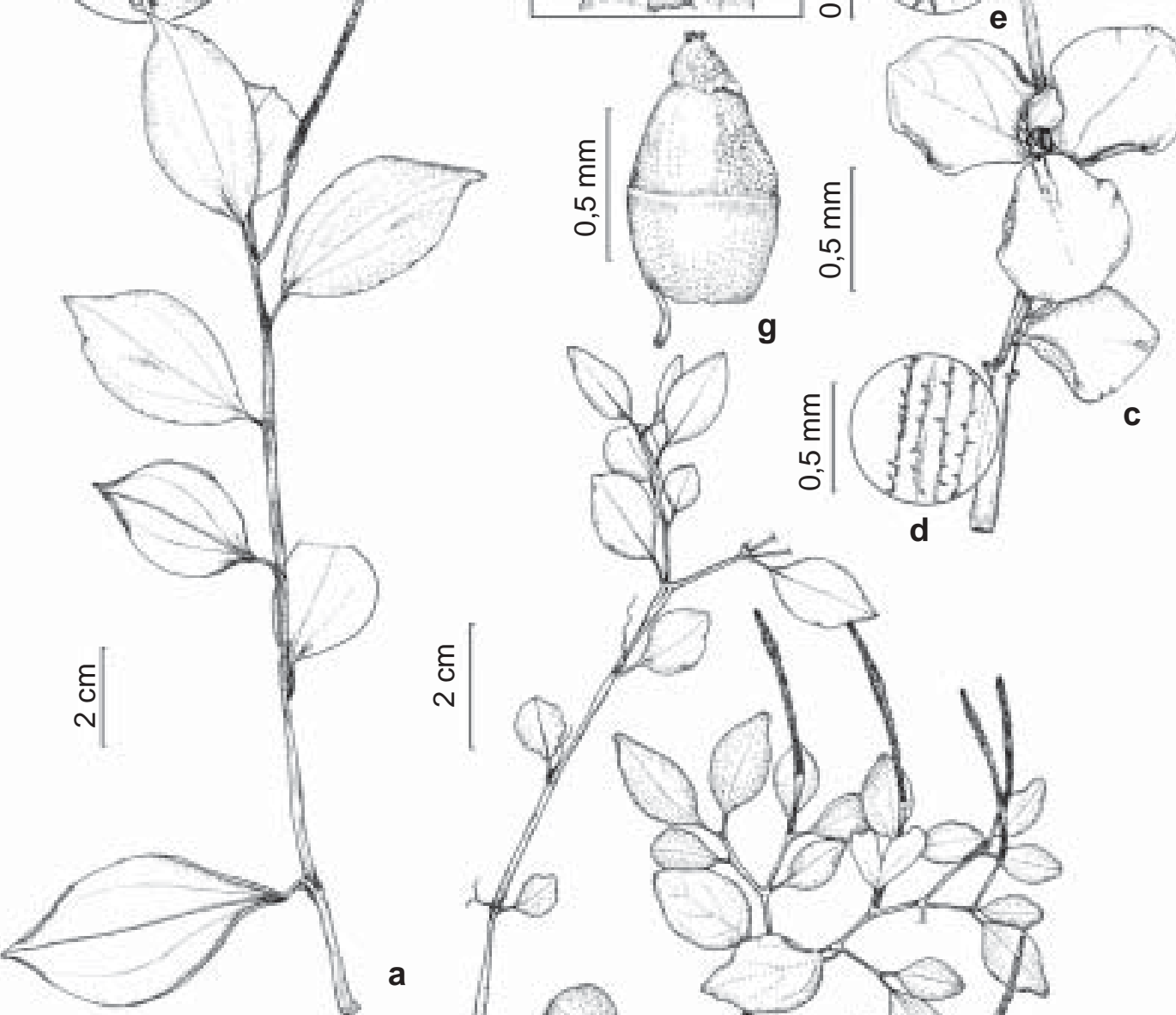

a
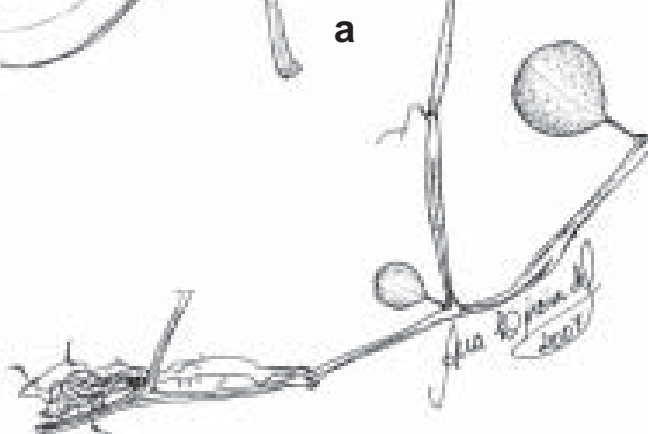

h

Figura 2-a-b. Peperomia augescens Miq. - a. hábito; b. ápice da lâmina cerdoso. c-g. P. catharinae Miq. - c. hábito; d. tricomas do ramo; e. tricomas do pedúnculo; f. detalhe da espiga em frutificação; g. fruto. h. P. clivicola Yunck. - h. hábito. (a Monteiro 128; b Monteiro 130; c-g Monteiro 56; h Lima 334). 
lanceolado-oblonga, base aguda, cuneada, não peltada, ápice agudo-acuminado, cerdoso, não emarginado, papirácea, não translúcida, discolor, nítida na face adaxial, esparsamente castanho-glandulosa na face abaxial, margem plana, eciliada; padrão de nervação misto, acródromo basal, camptódromo; nervuras 3, impressas na face adaxial, na abaxial proeminentes e vináceas. Espigas 7-15×0,1-0,2 cm, terminais, solitárias, eretas ou flexuosas, verde-claras; pedúnculo 1-1,6 cm compr.; raque foveolada, lisa; flores dispostas de forma pouco densa; bractéola arredondado-peltada, castanho-glandulosa, de margem inteira. Fruto ca. 1,5 mm compr., globosoovóide, ápice com escudo oblíquo, castanhoavermelhado a negro, glanduloso, pouco imerso na raque quando maduro; estigma subapical.

Distribuição geográfica e habitat: Brasil nos estados de Minas Gerais, Rio de Janeiro, São Paulo e Paraná. Aespécie, com distribuição restrita e esparsa é difícil de ser encontrada. No Rio de Janeiro, há registro apenas para o Parna do Itatiaia na floresta ombrófila densa montana. Material selecionado: Maromba, 1.100 ms.m., 13.II.1945, fl., A .C. Brade 17436 (RB); picada Barbosa Rodrigues, 25.II.1950, fl. e fr., A. C. Brade s.n. (RB-69192); trilha para a cachoeira Véu de Noiva, 4.VI.2005, fl., D. Monteiro \& G. Santos 128 (RB); trilha na margem do Lago Azul, descendo antes da ponte, 17.III.2006, fl., D. Monteiro et al. 148 (RB).

Peperomia augescens havia sido coletada pela última vez na região em 1950 por Brade. O táxon pode apresentar problemas na identificação, principalmente em material herborizado, devido a grande variação na forma e no tamanho das lâminas foliares nas fases de desenvolvimento. No Parna do Itatiaia, exemplares jovens apresentaram pouca ou nenhuma variação foliar; nos mais desenvolvidos, ao contrário, percebe-se a variação num mesmo ramo, por vezes nas folhas do ápice com relação às da base. Quando materiais apenas com folhas lanceoladas ou lanceoladooblongas são coletados, pode-se confundir o táxon com $P$. alata em estado jovem. As espécies se diferenciam, porém, pelo caule não alado e pelas folhas menores e não ciliadas em $P$. augescens. O táxon também se aproxima de
P. velloziana, diferindo pelo padrão de nervação. Miquel (1871) cita que P. augenscens apresenta "folhas inferiores muito menores obovado- elípticas, as demais ovado-oblongolanceolada". Algumas plantas coletadas na região apresentam uma variação semelhante, com folhas inferiores rômbico-ovadas de 3,7 $\times 2,7 \mathrm{~cm}$ e superiores lanceolado-oblongas de 4-6,5 × 1,9-2,7 cm. O nome do táxon vem do latim augesco, que quer dizer começar a crescer, multiplicar-se, provavelmente relacionado ao crescimento estolonífero da planta. Coletada com flor em fevereiro, março e junho; com fruto apenas em fevereiro.

4. Peperomia blanda (Jacq.) Kunth, Nov. Gen. Sp. 1: 67. 1815.

Erva $20-40 \mathrm{~cm}$ alt., epífita ou rupícola, umbrófila ou heliófila; ramos eretos, cilíndricos, suculentos, vináceos, ligeiramente sulcados quando secos, castanho-glandulosos, moderada a densamente curto vilosos, tricomas ca. $0,5 \mathrm{~mm}$ compr., acastanhados. Folhas opostas ou 3 verticiladas; pecíolo 5-13 mm compr., canaliculado, densamente viloso; lâmina 2,5-6 $\times 1,5-2,5(-3) \mathrm{cm}$, elíptica, eliptico-lanceolada, rômbico-eliptica, obovada, as da base diferente das do ápice, base aguda, decurrente, ápice agudo a acuminado, cartácea, translúcida, discolor, densamente castanho-glandulosa na face abaxial, com tricomas vilosos em ambas as faces, na face adaxial moderadamente dispostos em toda a lâmina, na abaxial ao longo das nervuras, margem plana, ciliada na metade superior em direção ao ápice; padrão de nervação misto, acródromo basal, camptódromo; nervuras 5-7, vináceas na face abaxial, bem como algumas partes da lâmina. Espigas 4,5$9 \times 0,1 \mathrm{~cm}$, axilares ou terminais, $1-3$, eretas; pedúnculo 1-2 cm compr., esparsa a moderadamente viloso; raque pouco verrucosa, glabra, castanho-glandulosa, com flores esparsamente dispostas; bractéola arredondada, peltada, glabra, castanho-glandulosa, de margem inteira. Fruto ca. $1 \mathrm{~mm}$ compr., globoso-ovóide, ápice com escudo oblíquo, negro, papiloso, pouco imerso na raque quando maduro, sem pseudocúpula basal; estigma subapical. 
Distribuição geográfica e habitat: Havaí, Jamaica, México, Américas Central e do Sul, exceto Belize, Peru e Uruguai. No Brasil ocorre em Roraima, Ceará, Pernambuco, Bahia, Mato Grosso, Distrito Federal e todos os estados das Regiões Sudeste e Sul. No Parna do Itatiaia ocorre na floresta ombrófila densa em altitudes de 800 a $1.800 \mathrm{~m}$.

Material selecionado: Monte Serrat $800 \mathrm{~ms} . \mathrm{m}$., 20.V.1935, fl. e fr., A. C. Brade 14635 (RB); picada Barbosa Rodrigues, 25.II.1950, fl. e fr., A. C. Brade 20192 (RB); sobre pedras em uma picada na mata, 16.II.1954, fl., H. Monteiro s.n. (RBR 16189); subida para o planalto, ca. 1.800 ms.m., 12.IV.1977, fl., G. Martinelli 1598 (RB); picada Campos Porto, 700800 ms.m., 25.IV.1983, fl. e fr., G. Martineli \& A. Chautems 9244 (RB); lote 22, casa 15, 22 ${ }^{\circ} 15^{\prime} 28^{\prime \prime S}$ 44³4'45"W, 13.III.1995, fl. e fr., $R$. Guedes et al. 2499 (RB, S, SP); próximo a ponte do Lago Azul, 4.VI.2005, fl. e fr., D. Monteiro \& G. Santos 115 (RB).

Os caracteres diagnósticos de Peperomia blanda são a filotaxia oposta ou 3-verticilada, os tricomas vilosos de moderada a densamente distribuídos nos ramos, em ambas as faces da lâmina e o tamanho das espigas. A grande variação na forma e tamanho da lâmina desta espécie, devido fatores ambientais, foi a causa atribuída por Yuncker (1974) a descrição de outros táxons que na verdade podem representam diferentes fases desta variação. Esta consideração demonstra a necessidade de mais estudos para sanar dúvidas quanto à taxonomia desta espécie que se constitui um complexo e para a qual são atualmente assinaladas 17 variedades. $\mathrm{O}$ nome do táxon vem do latim blanda, que significa branda, atrativa, de aparência agradável. Floresce e frutifica de fevereiro a junho.

\section{Peperomia catharinae Miq., Syst. Piperac.} 1: 127. 1843.

Fig. 2c-g

Erva ca. $6 \mathrm{~cm}$ alt., epífita, estolonífera, semi ciófila; ramos eretos, cilíndricos, hirtelo ou glabrescentes. Folhas 3 verticiladas; pecíolo 1-2 mm compr., canaliculado, hirtelo; lâmina 6-9×4-6 mm, elíptica, elíptico-obovada, base aguda à obtusa, ápice arredondado à obtuso, não emarginado, cartácea quando seca, levemente discolor, densamente castanho glandulosa na face abaxial, glabra em ambas as faces, margem plana, hirta a glabrescente; padrão de nervação misto, acródromo basal, camptódromo; nervuras 3, pouco perceptíveis. Espigas 7-10 $\times 1 \mathrm{~mm}$, terminais, solitárias, eretas, verde-claras; pedúnculo 11-16 mm compr., com tricomas hirtos, rígidos, mais longos que o dos ramos; raque densamente verrucosa, foveolada, glabra; flores densamente dispostas; bractéola arredondado-pelatada, densamente amarelo-glandulosa, com margem irregular, papilosa. Fruto 0,5-1 mm compr., oblongoovóide a elíptico, com ápice agudo, pouco imerso na raque, acastanhado, pseudopedicelado, pseudocúpula basal aparente, ocupando a metade inferior; estigma apical.

Distribuição geográfica e habitat: Uruguai, Argentina e Brasil, em todos os estados das Regiões Sudeste e Sul. No Parna de Itatiaia ocorre na floresta ombrófila densa montana.

Material examinado: na margem da estrada da sede para o centro de visitantes, 9.VIII.2004, fl. e fr., $D$. Monteiro et al. 56 (RB).

Material adicional examinado: SANTACATARINA: sem localidade, s.d., fl. e fr., C. B. Gaudichaud 282 (Isótipo P, foto).

Peperomia catharinae é pela primeira vez assinalada para o Parna do Itatiaia. Caracterizase por ser uma erva delicada, com tricomas dos ramos menores que os do pedúnculo, com folhas crassas e pequenas. Yuncker (1953, 1974) observou a ocorrência de 3-4 folhas no nó à ocasionalmente duas na parte inferior, lâminas glabras ou esparsamente puberulenta em ambas as faces e espigas de tamanho maior, 1-2(-2,5) cm compr. Guimarães et al. (1985) observaram até 4 folhas por nó e a raque papilosa nos espécimes da Serra dos Órgãos. O nome do táxon é uma referência à localidade da coleta do material-tipo. Coletada com flor e fruto apenas em agosto.

6. Peperomia clivicola Yunck., Bol. Inst. Bot. (São Paulo) 3: 158, fig. 142. $1966 . \quad$ Fig. 2h

Erva $10-25 \mathrm{~cm}$ alt., epífita ou rupícola, estolonífera, semi-umbrófila; ramos prostados, 
cilíndricos, vináceos, densamente hirtelos. Folhas alternas, ocasionalmente opostas; pecíolo 3-5 mm compr., canaliculado, moderada a densamente hirtelo; lâmina 1,5-3 $\times 0,6-1,5 \mathrm{~cm}$, ovada, ovado-elíptica, elíptica, elíptico-oblonga, base aguda, não cordada, ápice agudo a acuminado, cartácea, discolor, densamente castanho glandulosa em ambas as faces, esparsamente hirtela a glabrescente na face adaxial, moderada a esparsamente hirta ao longo da nervura central na face abaxial, margem plana; padrão de nervação misto, acródromo basal, broquidódromo; nervuras 3 . Espigas 2,5-3,5 ×0,1 cm, terminais, solitárias, eretas, verde-claras; pedúnculo 7-12 $\mathrm{mm}$ compr., moderadamente hirto; raque foveolada, moderadamente verrucosa, glabra; bractéola arredondado-peltada, densamente castanhoglandulosa, glabra, margem inteira ou ligeiramente irregular; flores densamente dispostas. Fruto ca. $5 \mathrm{~mm}$ globoso, ovóide a elíptico-ovóide, com ápice agudo, não rostrado, acastanhado, pouco imerso na raque, com pseudocúpula basal acima da porção mediana; estigma apical.

Distribuição geográfica e habitat: Brasil nos estados do Espírito Santo, Rio de Janeiro, São Paulo, Paraná e Santa Catarina. No Rio de Janeiro é encontrada apenas nos Parques Nacionais do Itatiaia e da Serra dos Órgãos. $\mathrm{Na}$ área em estudo ocorre de forma esparsa na floresta ombrófila densa, de 450 a $1.900 \mathrm{~m}$ de altitude. Segundo Guimarães et al. (1985), a planta também é pouco frequiente nas mesmas altitudes no Parna da Serra dos Órgãos.

Material selecionado: sem localidade, 18.VII.1902, $P$. Dusén 763 (Holótipo R); lote 31, 24.IX.1918, fl., C. Porto 739 (Parátipo RB); Serra do Itatiaia, 1.200 ms.m., 27.VI.1930, fl., A. C. Brade 10248 (Parátipo R); Maromba, trilha para a cachoeira Véu de Noiva, margem do rio Maromba, $22^{\circ} 15^{\prime} 28^{\prime \prime} \mathrm{S} 44^{\circ} 34^{\prime} 45^{\prime \prime} \mathrm{W}, 1.100$ ms.m., 15.IX.1994, fl., R. Guedes et al. 2458(RB); trilha para cachoeira Itaporoni, $1.050 \mathrm{~ms} . \mathrm{m} .$, 15.IX.1994, fl., R. Guedes et al. 2480 (RB); trilha do hotel Simon para os Três Picos, 22 $2^{\circ} 5^{\prime} 28^{\prime \prime} \mathrm{S} 44^{\circ} 34^{\prime} 45^{\prime \prime} \mathrm{W}, 1.500$ ms.m., 15.IX.1994, fl., M. P. M. Lima etal. 334(RB); Maromba, cachoeira Itaporoni, margem do rio Campo Belo, 22'15'28"S 44034'45"W, 1.100-1.150ms.m. 15.IX.1994, fl., M. P. M. Lima et al. 335 (RB, HUAn.v.).
Peperomia clivicola é de difícil determinação, por sua semelhança com $P$. corcovadensis. Yuncker (1974) comparou-a a P. corcovadensis f. longifolia (Dahlst.) Yunck., diferindo pelas partes mais densamente hirtelas, folhas mais lanceoladas e largas, com a nervura central da face abaxial hirtela. O autor observou ainda uma filotaxia ocasionalmente oposta, raque pouco verrucosa e bractéola com margem menos irregular. A análise de materiais da região, de outras localidades e de tipos nomenclaturais, mostram sobreposição destes caracteres que parecem assim, formar um complexo que está sendo analisado. O nome do táxon deriva do latim clivus (encosta) e íncola, (habitante, nativo de), referindo-se ao habitat da planta, em encostas da Serra do Itatiaia. Floresce e frutifica de junho a setembro.

7. Peperomia corcovadensis Gardner, Hooker's J. Bot. Kew Gard. Misc. 1: 187. 1842. Erva 6-15 cm alt., epífita ou rupícola, estolonífera, semi-ciófila; ramos prostados, ascendentes, cilíndricos, carnosos, sulcados quando secos, vináceos nos nós, com tricomas hirtelos, diminutos. Folhas alternas; pecíolo $3-$ $4 \mathrm{~mm}$ compr., canaliculado, hirtelo; lâmina 12,5 ×0,6-1,5 cm, ovado-lanceolada, elípticolanceolada, ovado-elíptica, base aguda, não cordada, ápice agudo, suculenta, papirácea quando seca, discolor, moderadamente castanho-glandulosa na face abaxial, nítida e glabra na face adaxial, face abaxial esparsamente hirtela a hirta ao longo da nervura principal a glabrescente, margem plana, hirtela ou glabrescente; padrão de nervação misto, acródromo basal, broquidódromo; nervuras 3. Espigas 2-4,5 $\times$ $0,1 \mathrm{~cm}$, terminais, solitárias, eretas, verdeclaras; pedúnculo 14-18 mm compr., hirto; raque moderada a densamente verrucosa, foveolada, glabra, moderadamente glandulosa; flores densamente dispostas; bractéola arredondado-peltada, densamente amareloglandulosa, glabra, com margem irregular. Fruto 0,3-1 mm, elíptico-ovóide a elíptico, com ápice agudo, não rostrado, acastanhado, profundamente imerso na raque, ocultando a 
pseudocúpula que se dispõe pouco abaixo ou até a porção mediana e se apresenta nítida e viscosa; estigma apical.

Distribuição geográfica e habitat: Brasil em todos os estados das Regiões Sudeste e Sul. No Rio de Janeiro ocorre com freqüência em remanescentes florestais. No Parna do Itatiaia é encontrada na floresta ombrófila densa montana e alto montana.

Material selecionado: picada do Maromba, 8.X.1945, fl. e fr., A. Barbosa 90 (RB); lote 50, 4.II.1948, fl., A. C. Brade 18814 (RB, NY n.v.); idem, 4.II.1948, fl. e fr., A. C. Brade 18818 (RB - parátipo de $P$. corcovadensisf. latifolia Yunck.); Macieiras, 1.900 ms.m., 28.II.1950, fl. e fr., A. C. Brade 20238 (RB); Taquaral, encosta a direita (descendo) do rio Campo Belo, 22¹5'28"S 44³4'45"W, 660 ms.m., 2.VIII.1995, fl., J. M. A. Braga et al. 2616 (RB); nas margens do rio Campo Belo, abaixo do Lago Azul, 22 ${ }^{\circ} 15^{\prime} 28^{\prime \prime S}$ 44³4'45"W, 800 ms.m., 13.IX.1995, fl., J. M. A. Braga et al. 2801 (RB); trilha para o Véu de Noiva, 1.200 ms.m., 10.VIII.2004, fl., D. Monteiro et al. 63 (RB); trilha para os Três Picos, 1.080 ms.m., 22²6' 16"S 44³6'49"W, 10.VIII.2004, fl., D. Monteiro et al. 64 (RB); trilha para a cachoeira do Itaporoni, 23.X.2004, fl., D. Monteiro et al. 91 (RB); Maromba, trilha depois da cachoeira do Escorrega, $1.021 \mathrm{~ms} . \mathrm{m}$. , 9.III.2005, fl. e fr., D. Monteiro et al. 100 (RB).

Material adicional examinado: RIO DE JANEIRO: Corcovado, s.d., fl., G. Gardner 119/2 (Holótipo $\mathrm{BM}$, foto).

Peperomia corcovadensis caracteriza-se pelas espigas eretas, verde-claras com raque verrucosa, ramos hirtelos, filotaxia alterna e lâminas ovado-lanceoladas, elíptico-lanceoladas a ovado-elípticas. As formas $P$. corcovadensis f. latifolia Yunck. e P. corcovadensis f. longifolia (Dahlst.) Yunck. não são consideradas e serão posteriormente analisadas, devido à grande variabilidade na forma e tamanho da lâmina, observada muitas vezes no mesmo material, o que dificulta a conceituação e interfere na manutenção das formas. As variações são aqui consideradas plasticidades, como já comentava Yuncker (1974), que sugere ser em decorrência de influências ambientais. O nome do táxon é relacionado à localidade da coleta típica, no Morro do Corcovado, Rio de Janeiro. Floresce e frutifica praticamente todo o ano.
8. Peperomia crinicaulis C.DC., Annuaire Conserv. Jard. Bot. Genève 2: 286. 1898.

Fig. 3d-h

Erva 12-20 cm alt., epífita, estolonífera, umbrófila; ramos prostados ou pendentes, quadrangulares, carnosos, angulosos e profundamente sulcados quando secos, moderada a densamente longo vilosos, tricomas 1-2,5 mm compr. Folhas 3-verticiladas; pecíolo 0,1-0,15 cm compr., canaliculado, viloso; lâmina 7-9 mm diâm., orbicular a ovado-orbicular, base arredondada, ápice obtuso a arredondado, ciliada, cartácea, discolor, translúcida, moderada a densamente vilosa em ambas as faces, margem plana; padrão de nervação misto, acródromo basal, broquidódromo; nervuras 3-5, mais comumente 3 . Espigas $1-2,5 \times 0,1 \mathrm{~cm}$, terminais, solitárias, flexuosas, verde-claras; pedúnculo 1,5$2,5 \mathrm{~cm}$ compr., moderadamente viloso; raque densamente verrocusa, foveolada, glandulosa, glabra; flores densamente dispostas; bractéola arredondado-peltada, glandulosa, glabra, com margem irregular. Fruto ca. 5 mm compr., globoso-ovóide, com ápice agudo, profundamente imerso na raque, castanho-glanduloso, pseudocúpula aparente, disposta muito acima da porção mediana; estigma apical.

Distribuição geográfica e habitat: Brasil em todos os estados da Região Sudeste e no Paraná. No Rio de Janeiro é rara, tendo sido coletada somente entre Paty do Alferes, Petrópolis e no Parna do Itatiaia onde ocorre em floresta ombrófila densa montana e altomontana, em altitudes de 570 a $1.700 \mathrm{~m}$.

Material examinado: Maromba, 1.700 ms.m., 20.II.1945, fl., A. C. Brade 17470 (RB); cachoeira do Itaporoni, 1.100 m.sm., trilha a direita da cachoeira, 1.VI.2006, fl., J. P. S. Condak et al. 460 (RB); trilha para o Alto dos Brejos, 28.X.2006, st., D. Monteiro et al. 194 (RB); trilha para os Três Picos, no início da trilha, 3.XII.2006, fl., D. Monteiro $\&$ A. C. Giannerine 230 (RB).

Material adicional examinado: SÃO PAULO: São José do Barreiro, Parque Nacional da Bocaina, trilha do ouro, mata de fundo de vale, 18.VII.1994, fl. e fr., L. Rossi \& E. Catharino 1594 (RB, SP n.v.); RIO DE JANEIRO: Petropolis, 15.VI.1875, st., A. F. M. Glaziou 8942 (G Holótipo, foto apud Yuncker 1974; P Isótipo, foto). 


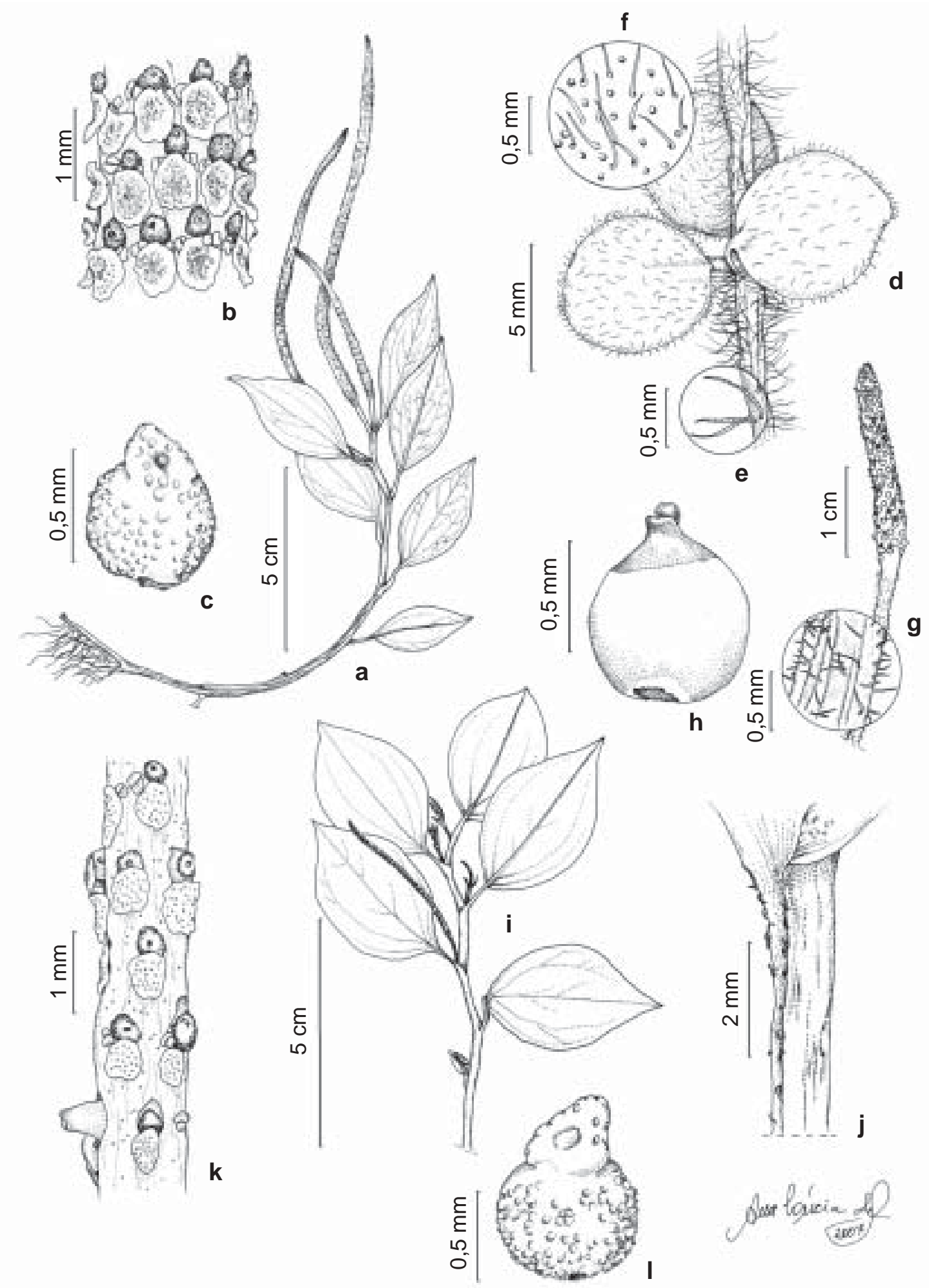

Figura 3 - a-c. Peperomia diaphanoides Dahlst. - a. hábito; b. parte da espiga em floração; c. fruto. d-h. P. crinicaulis C.DC. - d. ramo; e. tricomas do ramo; f. tricomas da lâmina foliar; g. espiga em floração e detalhe dos tricomas do pedúnculo; h. fruto. i-1. P. glabella (Sw.) A. Dietr. var. glabella. - i. hábito; j. pecíolo com linha de tricomas; k. parte da espiga em floração; 1. fruto. (a-c Dusén 761; d-g Condack 460; h Rossi 1594; i-1 Dusén 760). 
Peperomia crinicaulis é caracterizada pelos longos tricomas, profusamente distribuídos no caule e nas folhas orbiculares a ovadoorbiculares. Segundo Yuncker (1974) a margem da bractéola apresenta-se algumas vezes fimbriada ou mais ou menos setosa, o que não foi observado nos materiais examinados, onde se viu apenas irregularidades. Medeiros (2006), encontrou no Parque Estadual de Ibitipoca espécimes com folhas revolutas e com espigas e pedúnculo menores (até $1,8 \mathrm{~cm}$ e 1,4 cm compr., respectivamente), sendo o táxon pouco freqüente na região. O nome deriva do latim crinis (pêlo duro como crina), com referência ao tipo de tricoma. Coletada com flor nos meses de fevereiro, junho e dezembro.

9. Peperomia diaphanoides Dahlst., Kongl. Svenska Vetensk. Acad. Handl. 33 (2): 112, tab 10, fig. 3 e 4.1900.

Fig. 3a-c

Erva 13-16 cm alt., epífita, estolonífera, esparsamente glandulosa, glabra; ramos eretos, cilíndricos, não alados, ligeiramente sulcados quando secos. Folhas alternas; pecíolo 5-8 mm compr., canaliculado, sem linha de tricomas; lâmina 3-5×1,4-2(2,4) cm, ovada, ovado-elíptica, base aguda, decurrente, não peltada, ápice agudo-acuminado, cerdoso, não emarginado, membranácea quando seca, translúcida, esparsamente castanho-glandulosa, margem plana, ciliada acima da porção mediana até o ápice; padrão de nervação misto, acródromo basal, camptódromo; nervuras 3-5. Espigas 6-11 $\times 0,1-0,2 \mathrm{~cm}$ terminais, $1-3$, eretas; pedúnculo 9-13 mm compr.; raque foveolada, lisa; flores densamente dispostas; bractéola arredondadopeltada, glandulosa de margem inteira. Fruto 0,5-1 mm compr., globoso-ovóide, ápice com escudo oblíquo, pouco imerso na raque, marrom-castanhado; estigma subapical.

Distribuição geográfica e habitat: Brasil, nos estados de Minas Gerais, Rio de Janeiro, São Paulo, Paraná e Rio Grande do Sul. O Parna do Itatiaia constitui o único registro do táxon no estado do Rio de Janeiro.

Material examinado: Serra do Itatiaia, ca. 800 ms.m., 18.VII.1902, fl. e fr., P. Dusén 761 (R); serra do Itatiaia, sítio do Walter, IV.1926, fl., A. J. Sampaio 4163 (R).
Material adicional examinado: RIO GRANDE DO SUL, Santo Ângelo, 31.I.1893, fl., G. O. A. Malme 522 (Holótipo S, foto).

Peperomia diaphanoides se assemelha a P. hilariana, da qual difere pela ausência de tricomas, espigas maiores e pedúnculos menores. A espécie é pouco representada nas coleções, tendo sido pela última vez coletada na região no início do século XX. Yuncker (1974) examinou poucos materiais, que datam da mesma época, tendo observado tricomas na margem da lâmina em direção ao ápice e espigas menores. Dahlstedt (1900) descreveu uma diferença na forma e tamanho das folhas inferiores e superiores, sendo estas menores e magnas respectivamente, o que não foi observado nos espécimes do Parna. Medeiros (2006) encontrou a espécie entre 1.200-1.500 ms.m., com 15$30 \mathrm{~cm}$ alt., com folhas revolutas diferente dos exemplares aqui examinados. O nome do táxon vem do latim diaphanus (transparente) e oides (semelhante a), relacionado à semelhança com $P$. diaphana e por apresentar folhas translúcido-membranáceas, quando secas. Floresce e frutifica de abril a julho.

10. Peperomia galioides Kunth, Nov. Gen. Sp. 1: 71, tab. 17. 1815.

Erva ca. $20 \mathrm{~cm}$ alt, terrestre ou rupícola, umbrófila ou heliófila; ramos eretos ou ascendentes, com di ou tricotomia, suculentos, cilíndricos, ligeiramente vináceos na sombra e amarelados quando ao sol, anguloso-sulcados quando secos, moderada a densamente hirtelo a glabrescentes. Folhas 3-7 verticiladas, curto pecioladas, pecíolo ca. $1 \mathrm{~mm}$ compr., canaliculado, hirtelo; lâmina 1-2,2 (-3) $\times 0,3-0,5 \mathrm{~cm}$, oblonga, oblongo-lanceolada, base aguda, ápice obtuso, cerdoso, não emarginado, cartácea a membranácea, discolor, densamente amarelocastanho-glandulosa em ambas as faces, face adaxial glabrescente ou com tricomas hirtos esparsamente dispostos ao longo das nervuras, face abaxial glabra, margem plana; padrão de nervação misto, acródromo basal, camptódromo; nervuras 3 . Espigas $3-8 \times 0,1 \mathrm{~cm}$, terminais, $1-5$, eretas ou flexuosas, verde-claras; pedúnculo 
3-5 mm compr., hirtelo; raque foveolada, lisa, glabra; flores esparsas; bractéola arredondadopeltada, amarelo-glandulosa, glabra, de margem inteira. Fruto ca. $1 \mathrm{~mm}$ compr., ovóide, ápice com escudo oblíquo, pouco imerso na raque, acastanhado; estigma subapical.

Distribuição geográfica e habitat: México, Antilhas, América Central, Colômbia, Venezuela, Equador, Ilhas Galápagos, Peru e Bolívia. No Brasil ocorre em Roraima, Bahia, Goiás e em todos os estados das Regiões Sudeste e Sul. No Rio de Janeiro possui ampla distribuição e no Parna do Itatiaia ocorre na floresta ombrófila densa montana, alto-montana e nos campos de altitude.

Material selecionado: Serra do Itatiaia entre rochedos das Agulhas Negras, 30.XII.1895, fl., E. Ule $276(\mathrm{R})$; na base das Prateleiras, fl. e fr., 13.III.1960, fl. e fr., H. F. Martins 105 (RB, GUA); planalto, 13.I.1961, fl., H. E. Strang 339 (RB, GUA); abrigo Rebouças, 30.XII. 1966, fl., H. Strang \& A. Castellanos 795 (HB); Maromba, 3.II.1967, fl. e fr., H. Strang \& Castellanos 962 (HB); planalto, subida das Agulhas Negras, entre 2.400-2.500 ms.m., 6.II.1969, fr., D. Sucre 4644 (RB); estrada Registro-Agulhas Negras, km 3-4, 12.III.1975, fr., P. Occhioni 7095 (RFA); caminho para o Parque Nacional, via Engenheiro Passos, km 9,8, 18.II.1992, fl. e fr., M. V. Alves et al. 662 (GUA); planalto, proximidades da guarita do IBAMA, $22^{\circ} 15^{\prime} 28^{\prime \prime S} 44^{\circ} 34^{\prime} 45^{\prime \prime W}, 2.300$ ms.m., 24.I.1996, fl. e fr., J. M. A. Braga et al. 3213 (RB, S); trilha Prateleiras, após pedra da tartaruga, $2.300 \mathrm{~ms} . \mathrm{m}$., 19.IV.2005, fl. e fr., L. Freitas \& I. A. Aximoff 923 (RB); estrada para o planalto, próximo a pousada Alcene, 2.375 ms.m., 22 $22^{\prime} 10^{\prime \prime S} 44^{\circ} 42^{\prime} 73^{\prime \prime W}$, 11.VIII.2004, fl. e fr., D. Monteiro et al. 78 (RB); trilha para a cachoeira Véu de Noiva, 4.VI.2005, fl., D. Monteiro \& G. Santos 127 (RB); planalto, dentro das ruínas do antigo posto meteorológico, próximo ao Macena, 11.VIII.2006, fl., D. Monteiro et al. 183 (RB).

Peperomia galioides é uma espécie bem definida pelas lâminas oblongo-lanceoladas, 3 7 verticiladas e os ramos hirtelos. Segundo Langfield et al. (2004), a planta possui ação antibacteriana e antiparasítica. O nome do táxon vem do latim galea, que quer dizer capacete, provavelmente relacionado ao ápice oblíquo do fruto. Floresce e frutifica durante todo o ano.
11. Peperomia glabella (Sw.) A. Dietr. var. glabella, Sp. Pl. 1: 156. 1831 Fig. 3i-1 Erva 15-25 cm alt., epífita, estolonífera, umbrófila, densamente negro-glandulosa glabra; ramos eretos ou decumbentes, cilíndricos, carnosos, não alados, acastanhados e ligeiramente vináceos nos nós, angulosos quando secos. Folhas alternas; pecíolo 6-10 mm compr., canaliculado, com linha de tricomas, que às vezes se estende por uma pequena porção do ramo; lâmina 2-5,5 × 1,4-2,9 $\mathrm{cm}$, ovada, ovado-elíptica, ovado-lanceolada, base aguda a obtusa, não peltada, ápice agudo, acuminado, não emarginado cartácea, discolor, translúcida e densamente negro-glandulosa em ambas as faces, margem plana, eciliada; padrão de nervação misto, acródromo basal, camptódromo; nervuras 3, impressas na face adaxial. Espigas 6-9 $9 \times 0,1 \mathrm{~cm}$, axilares ou terminais, $1-3$, eretas, verde-claras; pedúnculo 7-13 mm compr.; raque lisa, foveolada, negro-glandulosa; flores esparsamente dispostas; bractéola elíptica a arredondada, peltada, densamente negroglandulosa, de margem inteira. Fruto ca. $2 \mathrm{~mm}$ compr., ovado-elíptico, ápice com escudo oblíquo, pouco imerso na raque quando maduro, marromacastanhado; estigma subapical.

Distribuição geográfica e habitat: Flórida, México, Antilhas, América Central, Colômbia, Venezuela, Guiana Francesa, Suriname, Equador, Peru e Bolívia. Brasil, nos estados do Amapá, Pará, Ceará, Bahia, Espírito Santo, Rio de Janeiro São Paulo e Santa Catarina. No Parna do Itatiaia ocorre de forma esparsa na floresta ombrófila densa montana.

Material examinado: Serra do Itatiaia, Monte Serrat, 13.VII.1902, fl., P. Dusén 760 (R); trilha para

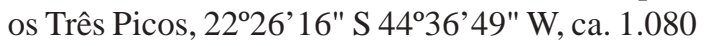
ms.m., 9.VIII.2004, st., M. Carvalho-Silva 292 (RB); trilha em direção a cachoeira do Itaporoni, 2.XII.2006, fl., D. Monteiro \& A. C. Giannerine 215 (RB); trilha em direção a piscina do Maromba, no final do trecho, 2.XII.2006, fl., D. Monteiro \& A. C. Giannerine 218 (RB, S, SP).

Peperomia glabella var. glabella, coletada no Parna do Itatiaia após 100 anos, é difícil de ser encontrada. O nome do táxon vem do latim glaber, por ser a planta glabra. Coletada com flor nos meses de julho e dezembro. 
11a. Peperomia glabella var. nigropunctata (Miq.) Dahlst., Kongl. Svenska Vetenskapsakad. Handl. 33 (2): 122.1900.

Diferencia-se da variedade típica por apresentar lâmina 2,5-4,5 × 1-2,2 cm, pecíolo glabro, sem linha de tricomas, além de ser mais densamente negro-glandulosa.

Distribuição geográfica e habitat: Antilhas, Américas Central e do Sul. Brasil nos estados do Rio de Janeiro e Santa Catarina. No Rio de Janeiro é pouco freqüente, sendo registrada nos Parques Nacionais da Serra dos Órgãos e do Itatiaia, Reserva Biológica do Tinguá e Parque Estadual da Ilha Grande. No Parna do Itatiaia ocorre de forma esparsa na floresta ombrófila densa montana.

Material examinado: estrada do Maromba, $\mathrm{km} 2,5$, 6.X.1945, fl. A. Barbosa \& W. Barbosa 91 (RB); lote 50, 4.II.1948, fl., A. C. Brade 18815 (RB); próximo a ponte do Maromba, ca. 1100 m.sm., 24.I.1962, fl., $H$. Monteiro 18/62 (RBR); margem do rio Campo Belo, perto do lote 17, 17.X.1977, fl., V. F. Ferreira 125(RB); trilha abaixo da ponte do rio Taquaral, 18.III.2006, fl., D. Monteiro et al. 157 (RB).

Material adicional examinado: RIO DE JANEIRO: Teresópolis, Parque Nacional da Serra dos Órgãos, caminho para o Dedo de Deus, 23.II.1984, fl. e fr., $L$. Mautone \& E. F. Guimarães 61 (RB).

Peperomia glabella var. nigropunctata encontrada na região após 29 anos, é aqui citado pela primeira vez para o Parque. Burger (1971) inclui esta variedade dentre os sinônimos de $P$. glabella, considerando na descrição a ocasional ocorrência de folhas opostas. $\mathrm{O}$ autor ainda comenta sobre a variação do tamanho da lâmina, quando a compara com P. alata. Howard (1973) mantêm os táxons em nível específico, diferindo-os em material fresco, pela coloração mais escura dos ramos e folhas e um menor número de espigas em $P$. nigropunctata. Guimarães et al. (1984) observaram papilas viscosas no fruto e pedúnculo com até $2 \mathrm{~cm}$ compr., o que não foi observado nos exemplares do Parna do Itatiaia. O nome do táxon vem do latim nigrans (negro, escuro) e punctatus (pontuado, pontilhado, marcado por glândulas) devido ao fato da planta possuir glândulas representadas por pontuações negro- glandulosas. Coletada com flor nos meses de outubro, janeiro, fevereiro e março.

12. Peperomia glazioui C. DC., Linnaea 37: 380. 1872.

Fig. 4a-c

Erva 10-15 cm alt., epífita ou rupícola, estolonífera, umbrófila; ramos quadrangulares, articulados, com sulcos profundos quando secos, moderado a densamente longo vilosos, tricomas 0,5-1 mm compr., amarelados, mais concentrados nos nós. Folhas opostas; pecíolo ca. $1 \mathrm{~mm}$ compr., densamente viloso; lâmina 5-15 × 4-10 mm, ovado-orbicular, obovadoelíptica, base obtusa ou subaguda, ápice obtuso a arredondado, crassa a cartácea, discolor, nervura central da face abaxial com tricomas curto-vilosos, esparsos, mais concentrados na base, raramente atingindo o ápice, face adaxial glabra, margem plana, ciliada; padrão de nervação misto, acródromo basal, broquidódromo; nervuras 3. Espigas $15-25 \times 1-2 \mathrm{~mm}$, terminais, 2 ou raro-solitárias; pedúnculo $5-14$ mm compr., esparso viloso a glabrescente, tricomas iguais aos do caule; raque foveolada, verrucosa, glabra; flores congestas; bractéola arredondada, glabra, com margem irregular. Fruto ca. $1 \mathrm{~mm}$ compr., elíptico, com ápice agudo, profundamente imerso na raque, marrom-acastanhado, pseudocúpula basal ocupando a metade do fruto, oculta pela raque; estigma apical.

Distribuição geográfica e habitat: Brasil, nos estados do Espírito Santo, Rio de Janeiro, São Paulo, Paraná, Santa Catarina e Rio Grande do Sul. No Parna do Itatiaia ocorre na floresta ombrófila densa montana com distribuição esparsa. Material examinado: lote 17, 24.X.1945, fl., A. Barbosa \& W. Barbosa 82 (RB); Hotel Donati, 18.IV.1962, fl. e fr., A. Castellanos 23329 (RB); sem localidade, 1.III.1970, fl. e fr., G. S. Melo s.n. (RB 148591); Taquaral, encosta a direita (descendo) do rio Campo Belo, 660 ms.m., 22 $2^{\circ} 15^{\prime} 28^{\prime \prime S} 44^{\circ} 34^{\prime} 45^{\prime \prime} \mathrm{W}$, 2.VIII.1995, fl., J. M. A. Braga et al. 2618 (RB).

Peperomia glazioui caracteriza-se pelos ramos quadrangulares, longo-vilosos com sulcos profundos e a escassa pilosidade que raro atinge o ápice da nervura mediana da face abaxial da lâmina de forma ovado-orbicular a obovado-elíptica. No Parna da Serra dos 

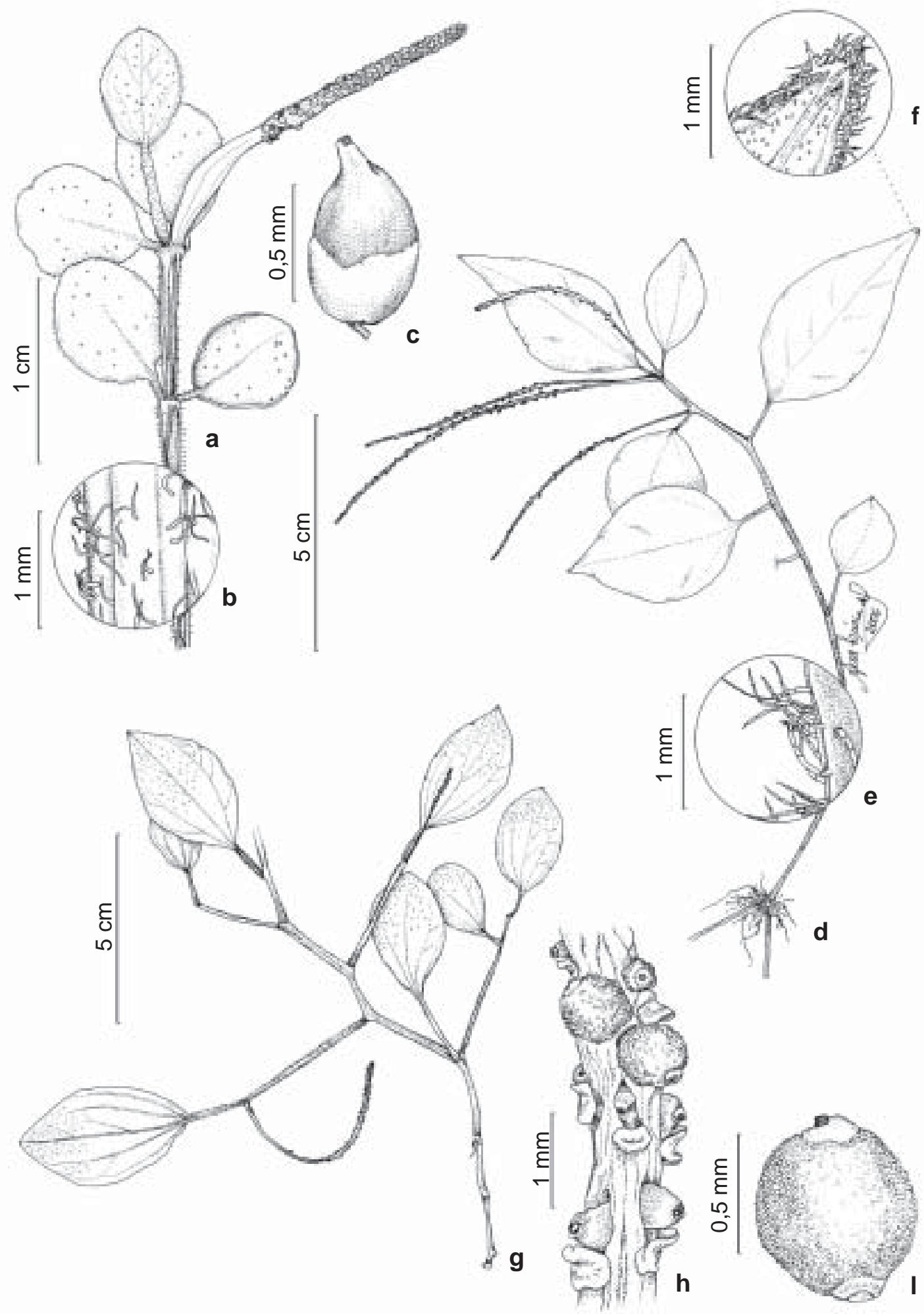

Figura 4 - a-c. Peperomia glazioui C.DC. - a. hábito; b. tricomas do ramo; c. fruto. d-f. P. hilariana Miq. - d. hábito; e. tricomas do ramo; f. margem da lâmina ciliada. g-i. P. itatiaiana Yunck. - g. hábito; h. parte da espiga em frutificação; i. fruto. (a-c Melo s.n. (RB 148591); d-f Monteiro 97; g-i Brade 14634). 
Órgãos, Guimarães et al. (1985) informam que a erva é pouco freqüente, com pedúnculo glabro, assim como nas espécies estudadas para o município do Rio de Janeiro (Ichaso \& Guimarães 1984). Yuncker (1974) observou esparsa pubescência na face adaxial da lâmina, o que não se verificou nos espécimes estudados e nem nas demais floras consultadas. No Parna do Itatiaia foi pela última vez coletada há 10 anos. O nome do táxon é dado em homenagem ao paisagista e coletor Auguste François Marie Glaziou (1828-1906). Coletada com flor nos meses de março, abril, agosto e outubro; com fruto em março e abril.

13. Peperomia hilariana Miq., Syst. Piperac. 1:89. 1843.

Fig. 4d-f

Erva ca. $20 \mathrm{~cm}$ alt., terrestre ou rupícola, semi-heliófila; ramos eretos, cilíndricos, sulcados quando secos, moderadamente vilosos, tricomas ca. $0,5 \mathrm{~mm}$. Folhas alternas da base ao ápice; pecíolo 8-14 mm compr., canaliculado, viloso; lâmina 3,5-5 ×1,8-2,4 cm, ovada, base aguda, ápice agudo, acuminado, cartácea, discolor, moderadamente castanho-glandulosa na face abaxial, glabra em ambas as faces ou às vezes com tricomas esparsos apenas na base da nervura principal da face adaxial, margem plana, ciliada, do ápice até a metade do tamanho da lâmina; padrão de nervação misto, acródromo basal, broquidódromo; nervuras 3. Espigas 4-6×0,1 cm, axilares ou terminais, eretas, 1-2, verde-claras; pedúnculo 1,5-2,5 cm compr., glabro; raque lisa, negroglandulosa, glabra; bractéola arredondadopeltada, glabra, glandulosa, de margem inteira. Fruto ca. $1 \mathrm{~mm}$ compr., globoso-ovóide, ápice com leve escudo oblíquo, densamente dotado de glândulas, pouco imerso na raque quando maduro; estigma subapical.

Distribuição geográfica e habitat: Brasil em todos os estados das Regiões Sudeste e Sul. No Rio de Janeiro ocorre apenas nos Parques Nacionais da Serra dos Órgãos e do Itatiaia, onde foi encontrada após 40 anos, na floresta ombrófila densa montana.

Material selecionado: rio Itatiaia, fazenda Santa Deolinda, 22.IV.1961, fl. e fr., A. Castellanos 23102
(GUA); Maromba 1.100 ms.m., 4.III.1962, fl., E. Pereira et al. 6988 (HB); trilha para os Três Picos, 1.150 ms.m., 22²6'16"S 44³6'37"W, 10.VIII.2004, fl., D. Monteiro et al. 76 (RB); margem esquerda do Rio Preto, 1.012 ms.m., 22²18'19"S 44³0'22"W, 8.III.2005, fl., D. Monteiro et al. 98 (RB); Maromba, trilha depois da cachoeira do Escorrega, 1.021 ms.m., 9.III.2005, fl. e fr., D. Monteiro et al. 103 (RB); trilha para a cachoeira Itaporoni, 5.VI.2005, fl., D. Monteiro \& G. Santos 133 (RB).

Material adicional examinado: Brasil, sem localidade, s.d., fl., F. Sellow s.n. (Isótipo P, foto apud Yuncker 1974).

Peperomia hilariana é de fácil identificação no campo, caracterizando-se principalmente pelos ramos eretos, moderada a densamente vilosos e pelas folhas alternas e ovadas. O nome do táxon foi dado em homenagem a Auguste François César Provençal de SaintHilaire (1779-1853). Floresce e frutifica de março a agosto.

\section{Peperomia hispidula var. sellowiana} (Miq.) Dahlst., Kongl Svenska Vetensk. Acad. Handl. 33(2): 14. 1900.

Erva 5-15 cm alt., delicada, estolonífera terrícola ou rupícola, semi-ciófila; ramos ascendentes, dicotomicamente ramificados, cilíndricos, carnosos, vináceos, glabrescentes ou com tricomas híspidos de ca. 0,5 mm compr. Folhas alternas, mais concentradas no ápice dos ramos; pecíolo 6-13 mm compr., canaliculado, glabrescente ou com tricomas híspidos esparsamente dispostos, mais concentrados no ápice; lâmina 0,9-1,5×1-2 cm, ovado-orbicular, orbicular, base e ápice obtuso a arredondado, membranácea, translúcida, com tricomas híspidos em ambas as faces, moderada a densamente dispostos, margem plana; padrão de nervação misto, acródromo basal, broquidódromo; nervuras 5. Racemos $1-2 \times 0,1 \mathrm{~cm}$, terminais ou mais raramente opostos às folhas, solitários, eretos; pedúnculo 1-1,8 cm compr., glabrescente a híspido; raque lisa, glabra; flores esparsas alternadamente dispostas; bractéola arredondada, glabra, de margem inteira. Fruto ca. $1 \mathrm{~mm}$ compr., ovóide à elíptico, com ápice agudo, glanduloso, glabrescente ou com tricomas vilosos, pedicelado, pedicelo ca. 0,2 mm compr.; estigma apical. 
Distribuição geográfica e habitat: Antilhas, Américas Central e do Sul. No Brasil, em Goiás e todos os estados das Regiões Sul e Sudeste. No Rio de Janeiro ocorre nos Parques Nacionais da Serra dos Órgãos e do Itatiaia, onde foi encontrada de forma frequiente (Guimarães et al. 1985). No Parna de Itatiaia ocorre na floresta ombrófila densa montana, em locais úmidos, próximo a quedas d'água, até $1.200 \mathrm{~m}$ alt.

Material selecionado: Serra do Itatiaia, cachoeira do Maromba, VI.1930, fl., A. C. Brade 10501 (R); Serra do Itatiaia, Taquaral, 19.V.1935, fl., A. C. Brade 14665 (RB); lote 17, 24.X.1945, fl., A. Barbosa \& W. Barbosa 85 (RB); lote 17, 900 ms.m., 16.II.1950, fl., A. C. Brade 20186 (RB); Maromba, 3.II.1967, fl., J. P. P. Carauta 362 (GUA); trilha para a cachoeira Véu de Noiva, 1.200 ms.m., 10.VIII.2004, fl., $D$. Monteiro et al. 60 (RB); trilha para os Três Picos, 1.160 ms.m., 22²6' 16"S 4436'37"W, 10.VIII.2004, fl., D. Monteiro et al. 75 (RB); trilha para a cachoeira Itaporoni, 23.X.2004, fl., D. Monteiro et al. 92 (RB); estrada de Itatiaia para Visconde de Mauá, 8.III.2005, fl. e fr., D. Monteiro et al. 96 (RB); trilha depois da cachoeira do Escorrega, 1.021 ms.m., 9.III.2005, fl. e fr., D. Monteiro al. 104 (RB); na estrada em direção ao Lago Azul, 4.VI.2005, fl. e fr., D. Monteiro \& $G$. Santos $118(\mathrm{RB})$.

Peperomia hispidula var. sellowiana é de fácil identificação. Possui ramos suculentos, translúcidos, que se apresentam vináceos, assim como as nervuras da face abaxial da lâmina. O porte da planta, os tricomas híspidos e brancos, lâmina ovada a orbicular e as inflorescências do tipo racemo caracterizam a espécie. O nome do táxon deriva do latim hispidus (híspido, provido de tricomas duros, longos e ralos). A variedade é em homenagem a Friedrich von Sellow (1789-1831). Floresce e frutifica por quase todo o ano.

15. Peperomia itatiaiana Yunck., Bol. Inst. Bot. (São Paulo), 3:183, fig 161. 1966.

Fig. 4g-i

Erva ca. $15 \mathrm{~cm}$ alt., com ramos eretos, algumas vezes em zigue-zague no ápíce, cilíndricos, moderadamente vilosos, tricomas 0,5-1 mm compr. Folhas alternas; pecíolo 11,5 cm compr., moderadamente viloso; lâmina
3,5-5×1,5-2,5 (3) cm, elíptica a elíptico-obovada, base aguda, não cordada, ápice agudo, membranácea quando seca, translúcida, esparso a moderadamente vilosa em ambas as faces, tricomas mais concentrados ao longo das nervuras da face abaxial, margem plana, ciliada; padrão de nervação acródromo-basal; nervuras 3-5, inconspícuas. Espigas 4-5×0,2 cm, terminais ou axilares, densamente florida; pedúnculo 1,5-3 cm compr., viloso; bráctea peduncular ausente; raque foveolada, lisa, obscuramente glandulosa, glabra; bractéola arredondado-peltada, glabra ,de margem inteira. Fruto globoso-ovóide, ápice com escudo oblíquo, não rostrado, pouco imerso na raque, marrom-acastanhado; estigma subapical.

Distribuição geográfica e habitat: ocorre apenas no Brasil, nos estados de São Paulo e Rio de Janeiro, onde foi registrada na região do planalto do Parna do Itatiaia.

Material examinado: planalto, $2.100 \mathrm{~ms} . \mathrm{m}$., 28.V.1935, fl. e fr., A. C. Brade 14634 (Holótipo-RB).

Peperomia itatiaiana ainda não recoletada na região, tem como único registro o material-tipo. O táxon assemelha-se a $P$. hilariana do qual difere pelos tricomas vilosos moderada a densamente distribuídos nos ramos e em ambas as faces da lâmina, caracteres diagnósticos desta espécie. O nome é dado em referência à localidade típica.

16. Peperomia mandioccana Miq., Linnaea 20: $125.1847 . \quad$ Fig. 5e-f

Erva 15-29 cm alt., rupícola, estolonífera, semi-umbrófila; ramos carnosos, cilíndricos, ligeiramente sulcados quando secos, moderada a densamente hirtelos. Folhas alternas na base, opostas a ocasionalmente ternadas no ápice (-4); pecíolo 4-6 mm compr., canaliculado, moderada a densamente hirtelo; lâmina 1,3$2,3 \times 0,7-1,4 \mathrm{~cm}$, ovada a ovado-elíptica, iguais da base ao ápice, base aguda a obtusa, ápice agudo, não emarginado, cartácea, densamente castanho-glandulosa e glabra em ambas as faces, margem plana, ciliada; padrão de nervação misto, acródromo basal, broquidódromo; nervuras 3 . Espigas $4,5-8 \times 0,1-0,2 \mathrm{~cm}$, terminais, solitárias; pedúnculo $1-2 \mathrm{~cm}$ compr., 
moderadamente hirtelo; raque verrucosa, foveolada, glabra; flores densamente dispostas; bractéola arredondada, densamente castanhoglandulosa, glabra, de margem inteira. Fruto ca. $1 \mathrm{~mm}$ compr., oblongo, ápice agudo, profundamente imerso na raque, ocultando a pseudocúpula basal, localizada apenas na metade inferior, acastanhado; estigma apical. Distribuição geográfica e habitat: Brasil nos estados de Minas Gerais, Rio de Janeiro e São Paulo. No Rio de Janeiro ocorre de forma pouco frequente nos Parques Nacionais da Tijuca, da Serra dos Órgãos e do Itatiaia, onde foi coletada na floresta ombrófila densa montana.

Material selecionado: Picada do Maromba, 8.X.1945, fl., A. Barbosa \& W. Barbosa 89 (RB); trilha do Hotel Simon para os Três Picos, 14.I.1997, fl. e fr., J. M. A. Braga et al. 3804 (RB).

Material adicional examinado: RIO DE JANEIRO, Serra da Mandioca, s.d., fl., C. F. P. Martius s.n. (Holótipo M).

O Parna do Itatiaia constitui uma nova localidade para Peperomia mandioccana no estado do Rio de Janeiro. A espécie é freqüentemente confundida com $P$. corcovadensis, da qual difere pela filotaxia alterna na base, oposta a ocasionalmente ternada no ápice (-4), ausência de pilosidade na lâmina e espigas de tamanho maior. Ichaso \& Guimarães (1984) observaram diferença na forma das folhas inferiores e superiores dos ramos, sendo estas arredondadas e elípticas a ovado-lanceoladas, respectivamente, o que não foi visto nos materiais do Parna do Itatiaia. Medeiros (2006) verificou que o táxon apresenta o ápice da lâmina às vezes emarginado e a margem revoluta, caracteres também não observados. O nome está relacionado à localidade da coleta do materialtipo. Coletada com flor em outubro e janeiro e com fruto apenas em janeiro.

17. Peperomia martiana Miq., Syst. Piperac. 1: 189.1843.

Erva 8-13 cm alt., epífita ou rupícola, estolonífera, semi-ciófila, glabra; ramos eretos, cilíndricos, suculentos, não alados, sulcados quando secos. Folhas alternas, concentradas no ápice dos ramos; pecíolo 4-8 mm compr., canaliculado; lâmina $1-2,2 \times 0,8-1,4 \mathrm{~cm}$, obovada, elíptico-obovada, base aguda, decurrente, não peltada, ápice obtuso a arredondado, emarginado, cerdoso, crassa a papirácea, discolor, obscuramente glandulosa, ligeiramente opaca na face adaxial, margem plana, ciliada; padrão de nervação misto, acródromo basal, broquidódromo; nervuras 5 , sendo a central impressa na face adaxial. Espigas 1,5-3,5 ×0,15 cm, terminais, eretas, solitárias, branco-esverdeadas; pedúnculo 1,7$2,5 \mathrm{~cm}$ compr.; raque lisa, foveolada; flores densamente dispostas; bractéola arredondadopeltada com poucas glândulas de margem inteira. Fruto ca. 1 mm compr., globoso a ovóide, ápice com escudo oblíquo, pouco imerso na raque quando maduro, avermelhado a marromacastanhado; estigma subapical.

Distribuição geográfica e habitat: Nicarágua, Costa Rica, Panamá, Colômbia, Equador e Peru. Brasil, em todos os estados das Regiões Sudeste e Sul. No Parna do Itatiaia foi encontrada na floresta ombrófila densa montana e alto-montana, em altitudes de 600-1.300 m.

Material selecionado: Lago Azul, 800 ms.m., 3.VII.1930, fl., A.C.Brade 10330 (R); lote 17, 24.X.1945, fl. e fr., A. Barbosa \& W. Barbosa 80 (RB); picada Barbosa Rodrigues, trilha paralela ao rio Campo Belo, 29.VIII.1989, st., L.C. Giordano et al. 796 (RB); trilha do Hotel Simon para os Três Picos, 22 ${ }^{\circ} 15^{\prime} 28^{\prime \prime S} 44^{\circ} 34^{\prime} 45^{\prime \prime W}, 1.300$ ms.m., 5.X.1994, fl., J.M.A. Braga et al. 1391 (RB); Taquaral, margem do rio Campo Belo 22 15 '28"S 44³4'45"W, 600 ms.m., 2.VIII.1995, fl. e fr., J.M.A. Braga et al. 2608 (RB); trilha atrás do abrigo IV, próximo ao rio, 4.VI.2005, fl., D. Monteiro \& G. Santos 119 (RB); no início da última trilha na estrada para ao Lago Azul, depois da ponte, 17.III.2006, fl. e fr., D. Monteiro et al. 153 (RB).

Peperomia martiana é caracterizada pela filotaxia alterna, folhas obovadas, emarginadas, mais concentradas no ápice dos ramos e pelos longos pedúnculos. $\mathrm{O}$ nome do táxon é em homenagem ao botânco alemão Karl Friedrich Phillipp von Martius. Coletada com flor de junho a outubro e em março e, com fruto em agosto, outubro e março. 


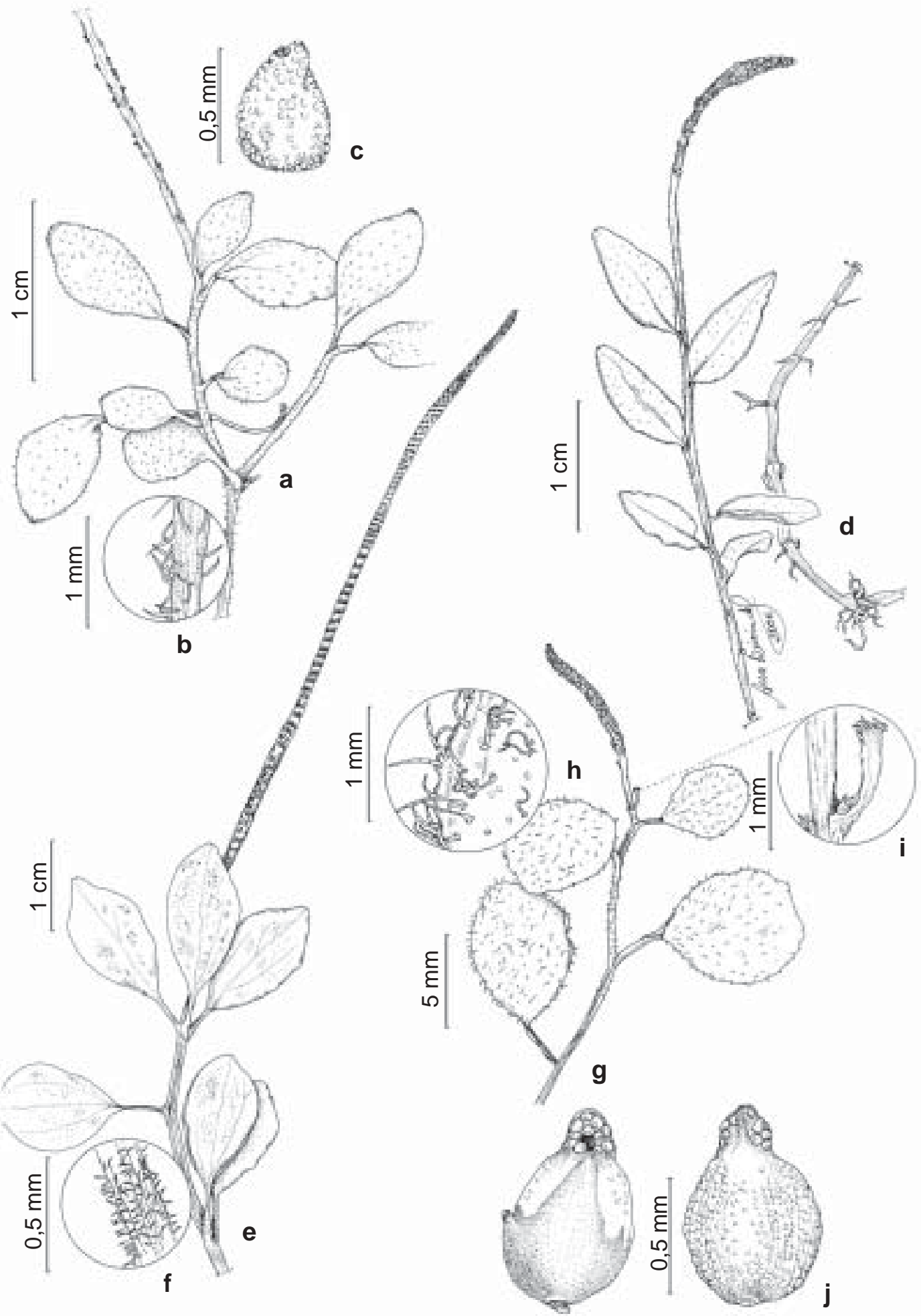

Figura 5 - a-c. Peperomia ouabianae C.DC. - a. hábito; b. tricomas vilosos do ramo; c. fruto. d. P. pseudoestrelensis C.DC. - d. hábito. e-f. P. mandioccana Miq. - e. parte do ramo; f. tricomas hirtelos do ramo. g-j. P. rotundifolia (L.) Kunth. - g. hábito; h. tricomas vilosos da face adaxial da lâmina; i. bráctea peduncular; j. fruto em visão anterior e posterior. (a-c Monteiro 125; d Câmara 11685; e-f Braga 3804; g-i Braga 2973; i Mattos 20362). 
18. Peperomia megapotamica Dahlst., Kongl. Svenska Vetensk. Acad. Handl. 33(2): 194, tab. 8, fig 1. 1900.

Erva 20-40 cm alt., terrestre ou rupícola, semi-ciófila, glabra; ramos eretos, crassos, vináceos, principalmente nos nós, cilíndricos a levemente anguloso-sulcado quando secos. Folhas 3-4 verticiladas; pecíolo 5-10 (-15) mm compr., canaliculado, moderadamente hirtelo a glabrescente; lâmina 4,5-7,5 × 2-3,5 cm, lanceolada, ovado-lanceolada, elípticolanceolada, iguais da base ao ápice, base aguda ou atenuada, ápice acuminado, papirácea a membranácea quando seca, translúcida, discolor, nítida na face adaxial, moderada a densamente castanho glandulosa em ambas as faces, margem plana, eciliada; padrão de nervação misto, acródromo basal, broquidódromo; nervuras 5. Espigas 8-16 $\times$ $0,1-0,2 \mathrm{~cm}$, terminais, $1-2$, eretas ou flexuosas; pedúnculo 1-2 cm compr., moderada a densamente hirtelo, vináceo na base; raque foveolada, lisa; flores densamente dispostas; bractéola elíptico-arredondada, densamente castanho-glandulosa, de margem inteira. Fruto 0,5-1 mm compr., ovóide, glanduloso, profundamente imerso na raque, castanho-avermelhado, pseudocúpula basal aparente, ocupando a metade ou mais da metade do fruto; estigma apical.

Distribuição geográfica e habitat: Brasil nos estados do Espírito Santo, Rio de Janeiro, Santa Catarina e Rio Grande do Sul. No estado do Rio de Janeiro é registrada apenas para os Parques Nacionais da Serra dos Órgãos e do Itatiaia, onde foi encontrada na floresta ombrófila densa montana, em altitudes de 800 a $1.100 \mathrm{~m}$.

Material selecionado: picada do Maromba, 8.X.1945, fl., A. Barbosa \& W. Barbosa 86 (RB, GUA); ponte do Maromba, proximidades das margens do rio Campo Belo, 22¹5'28"S 44³4'45"W, 1.100 ms.m., 4.XII.1996, fl., J.M.A. Braga et al. 3724 (RB); a margem da estrada a caminho da trilha para a Véu de Noiva, $22^{\circ} 25^{\prime} 73^{\prime \prime S}$ 4437'10"W, 1.037 ms.m., 23.X.2004, fl. efr., D. Monteiro et al. $88(\mathrm{RB})$; trilha para a cachoeira do Itaporoni, 23.X.2004, fl. e fr., D. Monteiro 93 (RB); trilha para os Três Picos, 3.XII.2006, fl. e fr., D. Monteiro \& A.C. Giannerine 236 (RB).
Material adicional examinado: RIO GRANDE DO SUL, São Leopoldo, 20.X.1892, fl., G.O.A. Malme 206 (Síntipo S).

Peperomia megapotamica é de fácil identificação, contribuindo para o seu reconhecimento a filotaxia verticilada, folhas grandes ovadas, elípticas a lanceoladas, além das longas espigas. Segundo Yuncker (1974), os ramos podem ser microscopicamente hirtelos a glabrescentes. O nome do táxon deriva do grego megas (grande) e potamós (rio), provavelmente com referência ao lugar de ocorrência da espécie, próximo a riachos. Floresce e frutifica de agosto a dezembro.

19. Peperomia ouabianae C.DC., Candollea 1: 400.1923.

Fig. 5a-c

Erva 5-17 cm alt., epífita, estolonífera, delicada; ramos ascendentes, cilíndricos, vilosos, tricomas ca. 0,5 mm compr., moderada a densamente dispostos. Folhas alternas; pecíolo 0,1-0,25 mm compr., canaliculado, esparso-viloso a glabrescente; lâmina 7-12×4-6 mm, elíptica, elíptico-ovada, elíptico-obovada, base aguda, não cordada, ápice agudo a obtuso, cartácea, discolor, moderadamente castanho glandulosa na face abaxial, modera a densamente vilosa na face adaxial e esparso vilosa a glabrescente face abaxial, margem plana, ciliada; padrão de nervação misto, acródromo basal, broquidódromo; nervuras 3. Espigas 2-3×0,1 cm, terminais, solitárias, verde-claras; pedúnculo 4-7 mm compr., esparso-viloso; bráctea peduncular ausente; raque foveolada, lisa, glandulosa, glabra; flores densamente dispostas; bractéola arredondado-peltada, glandulosa, glabra, de margem inteira. Fruto 0,5-1 mm compr., ovóide, sem pseudocúpula basal, ápice com escudo oblíquo, não rostrado, densamente glanduloso, castanhoavermelhado, pouco imerso na raque; estigma subapical.

Distribuição geográfica e habitat: Colômbia, Venezuela, Guiana e Brasil, nos estados de Roraima, Amapá, Espírito Santo, Rio de Janeiro e Paraná. No Rio de Janeiro ocorre apenas nos Parques Nacionais da Serra dos Órgãos e 
do Itatiaia, onde foi encontrada na floresta ombrófila densa montana.

Material examinado: trilha atrás do abrigo IV, próximo ao rio, 4.VI.2005, fl., D. Monteiro \& G. Santos 121 (RB); idem, 4. VI.2005, fl. e fr., D. Monteiro \& G. Santos 125 (RB).

Material adicional examinado: RORAIMA, Ouabiana, 1.400 ms.m., s.d., fl., E. Ule 8590 (Isótipo $\mathrm{K}$, foto).

O Parna do Itatiaia constitui uma nova localidade para Peperomia ouabianae no estado do Rio de Janeiro. O táxon, pouco representado nos herbários fluminenses, é caracterizado pelas lâminas pequenas, ovadas, elípticas a obovadas, e por possuir tricomas vilosos densamente distribuídos. Pode ser confundida com $P$. rotundifolia, em algumas de suas variações de forma e tamanho de lâmina, diferindo pelo comprimento das espigas e quantidade de tricomas. Yuncker (1974) comenta que existe uma variação no tamanho e forma das folhas de $P$. ouabianae que, junto com sua distribuição disjunta, indicam que a espécie pode constituir mais de um táxon. O nome está relacionado à localidade de coleta do material tipo. Coletada com flor e fruto em junho.

20. Peperomia pseudoestrellensis C.DC., Annuaire Conserv. Jard. Bot. Genève 2: 277. 1898.

Fig. 5d

Erva 5-7 cm alt., epífita ou terrestre, estolonífera, semi-ciófila; ramos cilíndricos, delicados, moderada a densamente hirtos, tricomas ca. 0,25 mm compr. Folhas alternas; pecíolo 1-3 $\mathrm{mm}$ compr., moderada a densamente viloso; lâmina (8-) 12-18 (-24)× 3-6 mm, lanceolada a elíptico-lanceolada, base aguda, não cordada, ápice agudo, às vezes ligeiramente emarginado, cerdoso, discolor, translúcido-membranácea, moderadamente glandulosa na face abaxial e moderadamente hirta em ambas as faces, tricomas mais profusos na nervura mediana, margem plana, ciliada; padrão de nervação misto, acródromo basal, broquidódromo; nervuras 3. Espigas 6$15(-20) \times 1 \mathrm{~mm}$, terminais, solitárias; pedúnculo 4-6 (-10) mm moderadamente hirto; raque foveolada, verrucosa, glabra; flores densamente dispostas; bractéola arredondada, densamente castanho-glandulosa, glabra, com margem irregular. Fruto 0,5-1 mm compr., elípticoovado a elíptico, profundamente imerso na raque, ocultando a pseudocúpula que se encontra abaixo da metade do fruto, ápice agudo, não rostrado; estigma apical.

Distribuição geográfica e habitat: No Brasil, em todos os estados da Região Sudeste, Paraná e Santa Catarina. Na área de estudo foi coletada na floresta ombrófila densa montana. Material examinado: lote 28, 16.II.1948, fl., A.C. Brade 18859 (RB); sem localidade, 21.IV.1972, fl., M. Marinho 11636 (RB, CESJ n.v.); próximo ao Véu da Noiva, 1.000-1.100 ms.m., 12.X.1977, fl., P.J.M. Maas \& G. Martinelli 3218 (RB, U n.v.); próximo ao abrigo 4, mata secundária, 22.V.1977, fl. e fr., $D$. Araújo 1706 (GUA).

Peperomia pseudoestrellensis foi pela última vez coletada no Parna há 30 anos, parece ser pouco freqüente na região. Os caracteres diagnósticos estão relacionados com o porte delicado, folhas alternas e pilosas em ambas as faces. A espécie é assim chamada por sua semelhança com P. estrellensis C.DC. cuja localidade do tipo é a mesma. Coletada com flor nos meses de fevereiro, maio e outubro e com fruto em maio.

21. Peperomia quadrifolia (L.) Kunth, Nov. Gen. Sp. 1: 69. 1815.

Erva ca. $15 \mathrm{~cm}$ alt., estolonífera, rupícola ou epífita, semi-heliófila, glabra; ramos eretos, cilíndricos, suculentos, crassos, com entre nós vináceos, anguloso-sulcados quando secos, às vezes dicotômicos. Folhas 3-6 verticiladas; pecíolo 2-3 mm compr., canaliculado; lâmina 9-13 × 5-7 mm, obovada, obovado-elíptica, base aguda, ápice obtuso a arredondado, emarginado, cerdoso, papirácea à coriácea, opaca, obscuramente glandulosa na face abaxial; padrão de nervação misto, acródromo basal, camptódromo; nervuras 3, a principal formando sulco discreto na face adaxial. Espigas 2,5-4×0,1-0,2 cm, terminais, solitárias, eretas; pedúnculo 1,2-2 cm; raque foveolada, verrucosa; flores densamente dispostas; bractéola arredondada, amarelo-glandulosa, 
com margem irregular. Fruto 0,5-1 mm compr., elíptico-ovóide, ápice agudo, moderadamente imerso na raque ocultando a pseudocúpula basal, que se dispõe até pouco abaixo da porção mediana, com aparência robusta, viscosa e nítida, glanduloso, negro a vermelho-acastanhado; estigma apical.

Distribuição geográfica e habitat: Jamaica, República Dominicana, Porto Rico, México, América Central, Colômbia, Venezuela, Guiana, Equador e Peru. No Brasil ocorre em Minas Gerais, Rio de Janeiro, São Paulo e Paraná. No Rio de Janeiro ocorre com pouca frequiência nos remanescentes florestais da Reserva Biológica do Tinguá e nos Parques Nacionais da Serra dos Órgãos e do Itatiaia, onde foi encontrada na floresta ombrófila densa montana.

Material examinado: Maromba, 1.000 ms.m., 3.III.1945, fl., F. Segadas-Vianna s.n. (RFA-22871); Taquaral, encosta a direita (descendo) do rio Campo Belo, 22 ${ }^{\circ} 15^{\prime} 28^{\prime \prime} \mathrm{S} 44^{\circ} 34^{\prime} 45^{\prime} \mathrm{W}, 660$ ms.m., 31.V.1995, st., J.M.A. Braga et al. 2434 (RB); estrada para o Hotel Donati, 11.VIII.2004, fl. e fr., D. Monteiro et al. 79 (RB); margem da estrada em direção a Véu de Noiva, 1.100 ms.m., 5.VI.2005, fl, D. Monteiro \& G. Santos 129 (RB, S).

Peperomia quadrifolia é de fácil reconhecimento no campo. Além de ramos estoloníferos e eretos, apresenta filotaxia verticilada, folhas papiráceas a coriáceas, pequenas, com ápice emarginado. $\mathrm{O}$ nome da espécie está relacionado à filotaxia foliar que, geralmente, se apresenta 4-verticilada. Floresce e frutifica em agosto e já foi encontrada com flor em março e junho.

\section{Peperomia rotundifolia (L.) Kunth, Nov.} Gen. \& Sp. 1: 65. 1815.

Fig. 5g-j

Erva 7-20 cm alt., epífita, estolonífera, reptante, delicada, semi-ciófila, esparsa a moderadamente vilosa, tricomas $0,5-1 \mathrm{~mm}$ compr.; ramos cilíndricos, delgados, sulcados quando secos. Folhas alternas; pecíolo 2-5 mm compr., esparso a moderadamente viloso ou glabrescente, canaliculado; lâmina 7-12 × 5$8 \mathrm{~mm}$, elíptico-obovada, elíptico-arredondada ou arredondada, base aguda a obtusa, não cordada, ápice obtuso a arredondado, emarginado, carnosa a papirácea quando seca, moderadamente castanho-glandulosa na face adaxial, esparsa a moderadamente vilosa em ambas as faces, margem plana, ciliada; padrão de nervação misto, acródromo basal, broquidódromo; nervuras 3 . Espigas 1,2-1,7×0,1 cm, terminais, solitárias; pedúnculo 3-6 mm compr., glabrescente; bráctea peduncular uma, 1-1,5 mm compr. próximo à base, espatulada, cerdosa no ápice, membranácea, glandulosa; raque glabra, vererucosa, foveolada; flores moderadamente dispostas; bractéola arredondada, glandulosa, glabra, de margem inteira. Fruto ca. $1 \mathrm{~mm}$ compr., elíptico-ovóide, sem pseudocúpula basal, ápice com escudo oblíquo, não rostrado, castanho-avermelhado, profundamente imerso na raque; estigma subapical.

Distribuição geográfica e habitat: Antilhas, México, Guatemala, Costa Rica e América do Sul, exceto Chile e Uruguai. No Brasil ocorre no Acre, Amazonas, Pará, Roraima, Pernambuco, Ceará, Bahia, Mato Grosso, Paraná, Santa Catarina e em todos os estados da Região Sudeste. No Parna do Itatiaia ocorre com pouca frequiência na floresta ombrófila densa montana. Material examinado: caminho Rio Bonito, 17.X.1945, st., A. Barbosa e W. Barbosa 83 (RB); lote 17, 24.X.1945, fl., A. Barbosa \& W. Barbosa 81 (RB); cachoeira Poranga, margem do rio Campo Belo, 22¹5'28"S 44³4'45"W, 8.XI.1995, fl., J.M.A. Braga et al. 2973 (RB); trilha em direção a cachoeira do Itaporoni, 2.XII.2006, fl., D. Monteiro \& A.C. Giannerine 214 (RB).

Material adicional examinado: RIO GRANDE DO SUL: ca. $20 \mathrm{~km}$ de Vacaria, 13.XI.1978, fl. e fr., J. Mattos 20362 (RB).

Peperomia rotundifolia é encontrada no dossel das árvores no Parna do Itatiaia, o que torna difícil a coleta. Os tricomas vilosos e as folhas elípticas, obovadas a arredondadas, constituem bons caracteres para diagnosticar a espécie, sendo de fácil reconhecimento no campo. Guimarães et al. (1985) observaram folhas sub-peltadas, espigas com até $2,5 \mathrm{~cm}$ compr. e estames com filetes curtos no Parna da Serra dos Órgãos. Yuncker (1950) comenta sobre a variação no tamanho, forma da lâmina 
e do tipo de tricoma, que pode ser crespopubescente ou viloso na mesma planta; esses caracteres podem servir para estabelecer formas ou variedades com estudos mais detalhados (Yuncker 1974). A bráctea peduncular é aqui descrita pela primeira vez, servindo como mais um caráter para a identificação do táxon. $\mathrm{O}$ nome do táxon vem do latim rotundus e folium, relacionado à forma arredonda das folhas. Coletada com flor e fruto de outubro a dezembro.

\section{Peperomia rubricaulis (Nees) A. Dietr.} Sp. Pl. 6: 182. $1831 . \quad$ Fig. 6a-c

Erva $20-40 \mathrm{~cm}$ alt., rupícola, estolonífera, ciófila, glabra; ramos eretos ou ascendentes, cilíndricos, crassos, vináceos quando jovens, profundamente anguloso-sulcados quando secos. Folhas 3-5 verticiladas; pecíolo 2-3 mm compr., canaliculado; lâmina 5-8×1,5-2,5 cm, oblongolanceolada, lanceolada, elíptico-lanceolada, iguais da base ao ápice, base aguda, cuneada, contraída, ápice agudo-acuminado, crassa a coriácea, discolor, subopaca, com pontuções, moderadamente glandulosa em ambas as faces, margem revoluta, eciliada; padrão de nervação acródromo basal; nervuras 3-5 impressas na face adaxial, proeminentes na face abaxial. Espigas $7-16 \times 0,1 \mathrm{~cm}$, terminais, $1-3$, flexuosas; pedúnculo $2-5 \mathrm{~cm}$ compr; raque foveolada, ligeiramente verrucosa; flores densamente dispostas; bractéola ovadoarredondada, peltada, glandulosa, de margem inteira. Fruto 1-1,5 mm compr., ovóide a elípticoovóide, ápice agudo, pouco imerso na raque quando maduro, deixando visível a pseudocupula basal que ocupa a metade do fruto; ápice ligeiramente oblíquo; estigma apical, papiloso.

Distribuição geográfica e habitat: Brasil nos estados de Minas Gerais, Rio de Janeiro e Paraná. No Parna do Itatiaia ocorre de forma pouco freqüente em floresta ombrófila densa montana. Material examinado: margem direita da estrada para o Véu de Noiva, ca. 1.100 ms.m., 19.III.2006, fl., D. Monteiro et al. 166 (RB).

Material adicional examinado: RIO DE JANEIRO: Rio Bonito, Distrito de Basílio, fazenda das Cachoeiras $13 \mathrm{~km} \mathrm{NE}$ da estrada Rio-Vitória, $150 \mathrm{~ms} . \mathrm{m}$., 13.VIII.1986, fl. e fr., G. Martinelli et al. 11633 (RB).
Peperomia rubricaulis, pela primeira vez citada para o Parna do Itatiaia, é de fácil reconhecimento no campo pelos ramos avermelhados, folhas verticiladas, grandes, crassas a coriáceas, oblongo-lanceoladas, lanceoladas ou elíptico-lanceoladas e pelo tamanho das espigas. Ichaso \& Guimarães (1984) encontraram folhas e espigas maiores nas espécies do município do Rio de Janeiro, além de ser a bractéola subovada e irregularmente denteada. O nome do táxon deriva do latim ruber, (vermelho) e caulis, (caule), em referência aos ramos vináceos ou avermelhados. Coletada com flor em março.

24. Peperomia subternifolia Yunck., Bol. Inst. Bot. (São Paulo) 3: 176, fig 156. 1966.

Fig. 6m

Erva ca. $13 \mathrm{~cm}$ alt., epífita ou terrestre, estolonífera, semi-ciófila; ramos eretos, cilíndricos, suculentos, vináceos, principalmente próximo à base, ligeiramente sulcados quando secos, moderada a densamente hirtelos. Folhas opostas ou 3verticiladas; pecíolo 3-7 (-10) mm compr., canaliculado; lâmina 1,3-1,8 $(-2,5) \times 0,8-1,3$ $(-1,9) \mathrm{cm}$, obovada a obovado-elíptica, iguais da base ao ápice, base aguda, ápice obtuso a arredondado, emarginado, carnosa a papirácea, discolor, nítida na face adaxial, densamente castanho-glandulosa na face abaxial, glabra em ambas as faces ou às vezes hirtela na base da nervura mediana da face adaxial, margem plana, eciliada; padrão de nervação misto acródromo basal, camptódromo; nervuras 3 , sendo a principal sulcada na face adaxial. Espigas 3-6,5 × 0,1 $\mathrm{cm}$, terminais ou axilares, solitárias, eretas ou flexuosas, verde-claras; pedúnculo 1,4-2 cm compr., hirtelo; raque bastante verrucosa, foveolada, glabra; flores densamente dispostas; bractéola arredondado-peltada, glandulosa, glabra, com margem irregular. Fruto 0,5-1 mm compr., elíptico-oblongo, oblongo-ovóide, acastanhado, ápice agudo a ligeiramente obtuso, imerso na raque, ocultando a pseudocúpula basal estreita; estigma apical. 


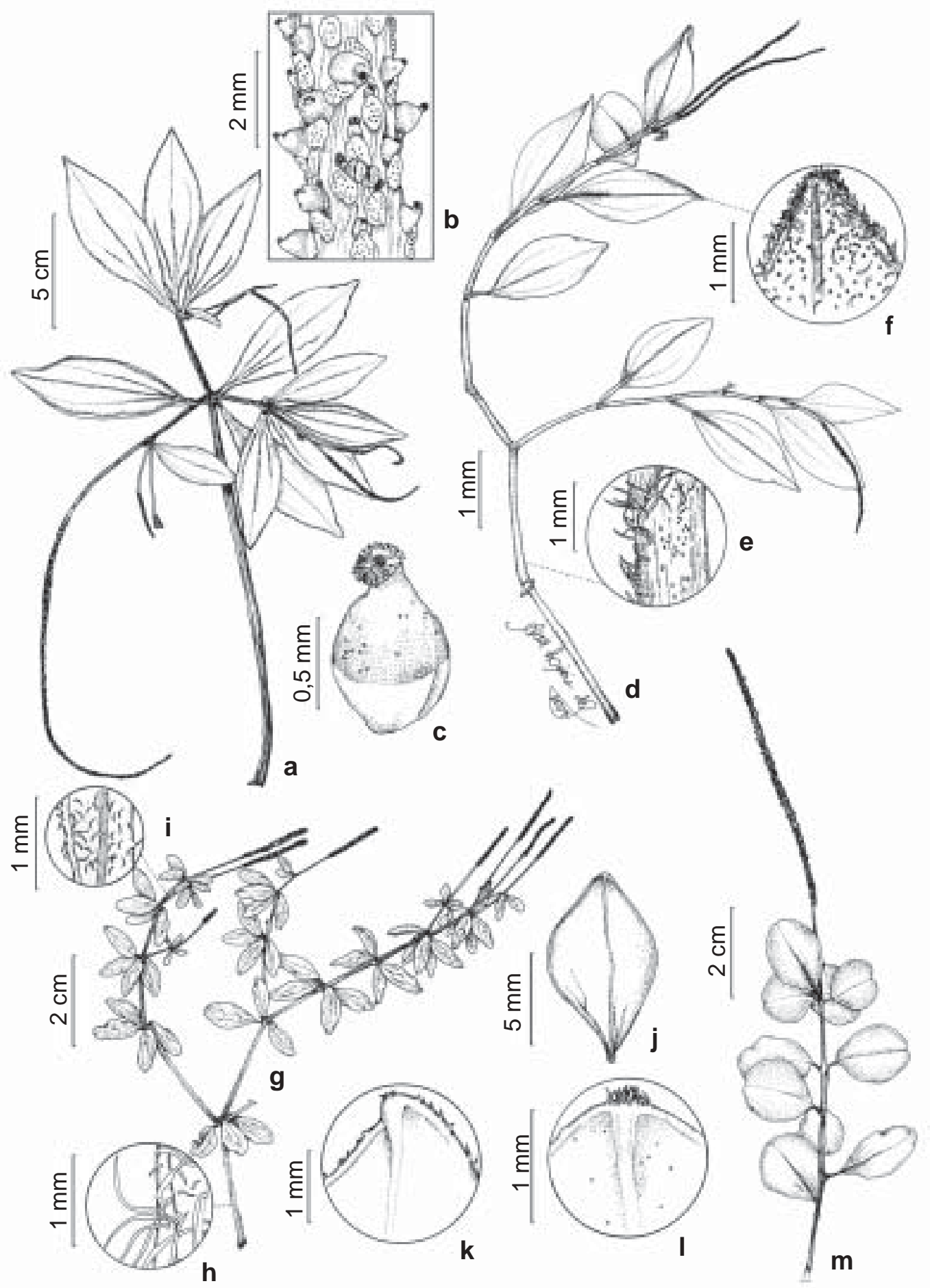

Figura 6 - a-c. Peperomia rubricaulis (Ness.) A. Dietr. - a. hábito ; b. parte da espiga em frutificação; c. fruto. d-f. P. trinervis Ruiz \& Pav. - d. hábito; e. tricomas do ramo; f. margem ciliada da lâmina foliar e face abaxial vilosa. g-i. P. tetraphylla var. tenera (Miq.) Yunck. - g. hábito; h. tricomas longo vilosos da base dos ramos; i. tricomas hirtos do ápice dos ramos. j-1. P. tetraphylla var. valantoides (Miq.) Yunck. - j. lâmina foliar; k. margem ciliada na metade superior; l. ápice cerdoso. m. P. subternifolia Yunck. - m. hábito. (a Monteiro 166; b-c Martinelli 11633; d-f Barbosa 84; g-i. Monteiro 237; j-k Landrum 2137; 1 Monteiro 83; m Braga 3805). 
Distribuição geográfica e habitat: Brasil, nos estados de Minas Gerais, Rio de Janeiro e São Paulo. No Rio de Janeiro só foi registrada nos Parques Nacionais da Bocaina e do Itatiaia, onde foi encontrada em áreas em bom estado de conservação, da floresta ombrófila densa montana e alto-montana.

Material selecionado: Macieiras, 11.X.1945, fl., A. Barbosa \& W. Barbosa 87 (RB, parátipo); sem localidade, 21.IV.1972, fl. e fr., U.C. Câmara 11688 (RB, CESJ n.v.); trilha do Hotel Simon para os Três Picos, 14.I.1997, fl. e fr., J.M.A. Braga et al. 3805 (RB); em fragmento de mata no Alto dos Brejos, 28.X.2006, fl., D. Monteiro et al. 200 (RB, SP).

Peperomia subternifolia assemelha-se a $P$. mandioccana da qual difere principalmente pela filotaxia oposta a 3-verticilada e por ser a lâmina mais larga, com o ápice emarginado. Além destas características, os tricomas hirtelos caracterizam o táxon, cujo nome está relacionado à filotaxia, que às vezes apresenta três folhas em cada nó. Encontrada com flor de outubro a abril e com fruto de janeiro a abril.

\section{Peperomia tenella (Sw.) A. Dietr., Sp. Pl} 1: 153.1831.

Erva ca. $10 \mathrm{~cm}$ alt., rupícola, estolonífera, ascendente, umbrófila, delicada; ramos eretos, cilíndricos, ligeiramente sulcados quando secos, glabrescentes, moderado a esparsamente hirsutos, tricomas ca. 0,5 mm compr. Folhas alternas; pecíolo 1,5-2 mm compr., canaliculado, glabro; lâmina 1-1,7 ×0,3-0,9 cm, ovada, ovado-lanceolada, elíptico-lanceolada, base aguda a obtusa, ápice agudo ou acuminado, às vezes, ligeiramente retuso, cerdoso, papirácea a sub-membranácea quando seca, glabra em ambas as faces, margem plana, eciliada; padrão de nervação misto, acródromo basal, broquidódromo; nervuras 3. Racemos 3,5-4,5 $\times 0,1 \mathrm{~cm}$, terminais, solitários, eretos, verdeclaros; pedúnculo 1-1,4 cm compr., glabro; raque glabra, lisa; flores moderadamente dispostas; bractéola elíptico-ovada, glabra, esparsamente glandulosa, de margem inteira. Fruto ca. 1,5-2 mm compr., elipciforme, afilando em direção a base, ápice agudo; pedicelo ca. 2 mm compr.; estigma apical.
Distribuição geográfica e habitat: Cuba, Jamaica, Honduras, Nicarágua, Costa Rica, Panamá, Colômbia, Venezuela e Guiana. No Brasil ocorre no Amazonas, Minas Gerais, Rio de Janeiro, São Paulo, Paraná e Santa Catarina. No Rio de Janeiro é registrada apenas para os Parques Nacionais da Serra dos Órgãos e do Itatiaia, onde foi coletada em locais úmidos da floresta ombrófila densa montana.

Material examinado: Serra do Itatiaia, Três Picos, 27.VI.1930, fl., A.C. Brade s.n. (pró-parte R- 22722); trilha do Hotel Simon para os Três Picos, 14.I.1997, fl. e fr., J.M.A. Braga et al. 3806 (RB); trilha da cachoeira Véu de Noiva, próximo a ponte do Maromba, 1.100 ms.m., 4.VI.2005, fl. e fr., $D$. Monteiro \& G. Santos 126 (RB); trilha em direção as cachoeiras Itaporoni e Véu de Noiva, 1.200 ms.m., 5.VI.2005, fl. e fr., D. Monteiro \& G. Santos 132 (RB).

Peperomia tenella assemelha-se no campo quando estéril à $P$. pseudoestrelensis, diferindo desta, porém, por apresentar ramos hirsutos a glabrescentes, lâmina glabra em ambas as faces e, quando fértil, pelo tipo de inflorescência. Guimarães et al. (1984) e Yuncker (1974) encontraram tricomas esparsos na face adaxial da lâmina, o que não foi observado no material examinado. O nome do táxon deriva do latim tenellus (delgado, macio), com referência ao habito delicado da planta. Floresce e frutifica de janeiro a junho.

26. Peperomia tetraphylla (G. Forst.) Hook. \& Arn., Bot. Beechey Voy. 97. 1832.

Erva 7-12 cm, epífita ou rupícola, estolonífera, reptante, cespitosa, semiumbrófila; ramos prostados, ascendentes ou eretos, cilíndricos, com entre nós vináceos, anguloso-sulcados quando secos, esparsa a densamente hirtos ou glabrescentes, tricomas ca. 0,2 mm compr. Folhas 3-4 verticiladas; pecíolo 1-2 (-4) mm compr. glabrescente ou levemente hirto, canaliculado; lâmina 6-13× 4-9 mm, ovada, rômbico-ovada, rômbicoelíptica, rômbica, base atenuada, aguda, ápice agudo a obtuso, às vezes contraído e cerdoso, não emarginado, coriácea, opaca, discolor, 
glanduloso-impresso pontuada em ambas as faces, hirta em ambas as faces, glabrescente na face adaxial ou em ambas as faces, por vezes ciliada; padrão de nervação misto, acródromo basal, broquidódromo; nervuras 3 . Espigas 1,5-2,5 $\times 0,1-0,15 \mathrm{~cm}$, terminais ou axilares, 1-3 eretas, verde-claras a brancoamareladas; pedúnculo 1-2 cm compr., moderada a densamente hirto, com tricomas do mesmo tamanho que o dos ramos; raque densamente coberta por tricomas híspidos; flores densamente dispostas; bractéola arredondada, densamente castanho-glandulosa, glabra, de margem inteira. Fruto 0,3-1 mm, elíptico, com ápice agudo, castanho- avermelhado, imerso na raque, ocultando a pseudocúpula basal; estigma apical.

Peperomia tetraphylla é de fácil reconhecimento e pode ser cultivada como ornamental (Guimarães \& Giordano 2004). Os ramos prostados, ascendentes ou eretos, com entre nós vináceos, folhas quatro verticiladas, variegadas e suculentas, espigas com raque pilosa caracterizam o táxon. Yuncker (1974) diferenciou as variedades pelo tamanho da lâmina. Este caráter, porém, mostrou-se variável se sobrepondo nas variedades, sendo melhor utilizar apenas os tricomas. Os índios usam a planta na forma de infusão para banhos externos (Milliken 1997).

\section{Chave para as variedades de $\boldsymbol{P}$. tetraphylla no Parna do Itatiaia}

1. Lâmina foliar glabrescente em ambas as faces, por vezes cerdosa no ápice ou ciliada apenas na metade superior 26c P. tetraphylla var. valantoides

1'. Lâmina foliar provida de tricomas em uma ou ambas as faces, ciliada em toda a margem

2. Ramos com tricomas de mesmo comprimento da base até o ápice.

26a P. tetraphylla var. tetraphylla

2'. Ramos com tricomas da base diferentes dos do ápice 26b P. tetraphylla var. tenera

26a. Peperomia tetraphylla (G. Forst.) Hook \& Arn. var. tetraphylla, Bot. Beechey Voy. 97. 1832.

Ramos densamente hirtos, com tricomas do mesmo comprimento da base até o ápice. Lâmina foliar hirta em ambas as faces ou glabrescente na face adaxial, ciliada em toda a margem.

Distribuição geográfica e habitat: Trinidad, Cuba, Porto Rico, Jamaica, México, Américas Central e do Sul, exceto Belize, Nicarágua, Suriname, Chile e Uruguai, China, Etiópia, Uganda, Índia, Malásia, Nova Zelândia, Filipinas, Taiwan e Tailândia. Brasil, nos estados de Ceará, Pernambuco, Bahia, Mato Grosso, Goiás, Distrito Federal e em todos os estados das Regiões Sudeste e Sul. No Parna ocorre na floresta ombrofila densa alto-montana. Material examinado: trilha para a cachoeira do Escorrega, 22²0'87"S 4437'21"W, 1.660 ms.m., 6.XII.2006, fl., M. S. Yepes \& A.A. Carvalho s.n. (RB -435413).
O nome da variedade deriva do grego tetra (quatro) e phyllon (folha), referindo-se às folhas 4-verticiladas. Coletada com flor em dezembro.

26b. Peperomia tetraphylla var. tenera (Miq.) Yunck., Bol. Inst. Bot. (São Paulo) 3: 179. 1966.

Fig. 6g-i

Caracteriza-se pelos ramos com tricomas hirtos no ápice e longo vilosos na base, medindo 0,5-1 mm compr. e pelas folhas hirtas em ambas as faces, ciliada em toda a margem.

Distribuição geográfica e habitat: Brasil em todos os estados das Regiões Sudeste e Sul. No estado do Rio de Janeiro foi registrada em Parati, Grumari e nos Parques Nacionais da Serra dos Órgãos e do Itatiaia, onde ocorre na floresta ombrofila densa montana, alto-montana e campos de altitude.

Material examinado: planalto 2.400 ms.m., 14.XI.1954, fl., A.C. Brade \& G.F.J. Pabst, s.n. (HB-10276); trilha do Hotel Simon para os Três Picos, 22¹5'28"S 44³4'45"W, 1.500 ms.m., 23.XI.1994, fl., J.M.A. 
Braga et al. 1625 (RB); trilha para o Alto dos Brejos, 28.X.2006, fl., D. Monteiro et al. 197 (RB); quase no final da trilha para os Três Picos, 3.XII.2006, fl., D. Monteiro \& A.C. Giannerine 237 (RB).

$\mathrm{O}$ nome da variedade deriva do latim tener (tenro, macio). Coletada com flor de outubro a dezembro.

26c. Peperomia tetraphylla var. valantoides (Miq.) Yunck., Bol. Inst. Bot. (São Paulo) 3: 178. 1966.

Fig. 6j-1

Difere da variedade típica pelos ramos esparsamente hirtos a glabrescentes e lâmina foliar glabrescente em ambas as faces, por vezes cerdosa no ápice ou ciliada apenas na metade superior.

Distribuição geográfica e habitat: Brasil, nos estados do Espírito Santo, Rio de Janeiro, São Paulo e Santa Catarina. No Rio de Janeiro é conhecida apenas para os Parques Nacionais da Serra dos Órgãos e do Itatiaia, onde foi encontrada com pouca freqüência na floresta ombrófila densa montana, alto-montana e nos campos de altitude, entre 850 e 2.600 ms.m.

Material selecionado: próximo à Registro 1.800 ms.m., 14.XI.1954, fl. e fr., A. C. Brade \& Pabst s.n. (HB-10278); encosta, nas margens do rio Campo Belo, abaixo do Lago Azul, 22 $15^{\prime} 28^{\prime \prime S} 44^{\circ} 34^{\prime} 45^{\prime \prime} \mathrm{W}$, 800 ms.m., 26.IX.1995, fl. e fr., J. M. A. Braga et al. 2834 (RB); estrada que leva ao abrigo Rebouças, 18.X.1997, fl., V. F. Ferreira 225 (RB); along road to Agulhas Negras, $22^{\circ} 25^{\prime}$ S 444ㅇ' W, 2.000-2.600 ms.m., on wet bank, 18.X.1997, fl., L. R. Landrum 2137 (RB); trilha para os Três Picos, 1.080 ms.m., 22²6' 16"S 44³6'49"W, fl., 10.VIII.2004, D. Monteiro et al. 66 (RB); trilha para oAlto dos Brejos, 28.X.2006, fl., D. Monteiro et al. 195, 196 (RB); trilha em direção a cachoeira do Itaporoni, 2.XII.2006, fl., D. Monteiro \& A. C. Giannerine 217 (RB).

O nome do táxon é por sua semelhança com as plantas do gênero Valantia L. (Rubiaceae). Coletada com flor em maio e de agosto a dezembro e com fruto em setembro e novembro.

27. Peperomia trinervis Ruiz \& Pav., Fl. Peruv. 1: 32, tab. 50, fig. b. 1798.

Fig. 6d-f

Erva 14-25 cm alt., epífita ou rupícola, estolonífera, semi-ciófila, moderada a densamente negro-glandulosa; ramos decumbentes, carnosos, cilíndricos, vináceos próximo à base e aos nós, sulcados quando secos, moderadamente vilosos, tricomas ca. $0,5 \mathrm{~mm}$ compr., às vezes formando uma linha. Folhas alternas; pecíolo 6-10 mm compr., canaliculado, viloso; lâmina 3-4,5×1,3-2 cm, elíptica, elíptico-lanceolada, elíptico-ovada, base aguda, decurrente, não cordada, ápice agudo, acuminado, papirácea, discolor, nítida na face adaxial, densamente negro-glandulosa em ambas as faces, glabrescente à esparso-vilosa na face adaxial, esparso a moderadamente vilosa na face abaxial, margem plana, ciliada no ápice; padrão de nervação acródromo basal; nervuras 3 . Espigas 4,5-6,5 $\times 0,1 \mathrm{~cm}$, axilares ou terminais, 1-3, eretas, branco-amareladas; pedúnculo $7-$ 10 mm compr., glabrescente; bráctea peduncular ausente; raque verrucosa, foveolada, glandulosa, glabra; flores esparsas; bractéola arredondadopeltada, densamente castanho-glandulosa, glabra, de margem inteira. Fruto ca. 1 mm compr., globoso-ovóide, sem pseudocúpula basal, ápice com escudo oblíquo, não rostrado, negroacastanhado, glanduloso, pouco imerso na raque; estigma subapical.

Distribuição geográfica e habitat: México, Colômbia, Equador, Peru e Bolívia. Brasil, no estado da Bahia e em todos os estados da Região Sudeste. No Rio de Janeiro ocorre em Petrópolis e no Parna do Itatiaia, onde foi encontrada de forma restrita e esparsa, na floresta ombrófila densa montana.

Material examinado: picada Barbosa Rodrigues, 20.X.1945, fl., A. Barbosa \& W. Barbosa 84 (RB); trilha em direção a cachoeira do Itaporoni, 2.XII.2006, fl., D. Monteiro \& A. C. Giannerine 212 (RB).

Material adicional examinado: SÃO PAULO: Votorantim, represa de Sorocaba, 14-23.III.1979, fl. e fr., V.F. Ferreira 567 (RB). PERU, Chinchao, s.d., fl., H. Ruiz \& J.A. Pavón s.n. (Holótipo MA, foto).

O espécime A. Barbosa 84 encontravase em Yuncker (1974), determinado como P. glabella var. nervulosa (C.DC.) Yunck. Apesar de morfologicamente semelhantes, $P$. trinervis difere por possuir folhas maiores, vilosas e ramos também vilosos. Ichasso \& Guimarães (1984) observaram em Santa 
Catarina que as folhas dos ramos inferiores de alguns espécimes de $P$. trinervis por vezes se mostram orbiculares, além de possuirem espigas maiores, o que não foi observado no material examinado. Trelease (1936) e Yuncker (1974) citam o tamanho da espiga entre 6-10 $\mathrm{cm}$ de comprimento, entretanto os materiais de Itatiaia possuem espigas menores. O Parna do Itatiaia constitui uma nova localidade dessa espécie no Rio de Janeiro, onde é difícil de ser encontrada. O nome do táxon deriva do latim trinervis, (trinérvio, com três nervuras), relacionado as três nervuras basais da lâmina foliar. Coletada com flor em outubro e dezembro.

28. Peperomia trineura Miq., Syst. Piperac. 1: 175.1843.

Fig. 7c

Erva 15-25 cm alt., epífita ou rupícola semi-ciófita; ramos eretos, crassos, quandragulares, anguloso-sulcados quando secos, glabros ou esparsamente hirtelos. Folhas 4-8 verticiladas subsésseis; pecíolo $1-2 \mathrm{~mm}$ compr., canaliculado, hirtelo; lâmina 8-13×3$6 \mathrm{~mm}$, rômbico-elíptico-lanceolada, base aguda, contraída, ápice agudo a acuminado, fortemente contraído, cerdoso ou esparsamente hirtelo na metade superior, não emarginado, crassa a coriácea, moderadamente impresso-glandulosa na face abaxial, glabra em ambas as faces, margem revoluta, eciliada; padrão de nervação acródromo basal; nervuras 3 , impressas na face adaxial. Espigas 5-9,5 $\times 0,1-0,2 \mathrm{~cm}$, terminais, solitárias, eretas, verde-claras; pedúnculo $1-2 \mathrm{~cm}$ compr., glabro; raque foveolada, lisa, glabra; flores densamente dispostas; bractéola arredondado-peltada, glandulosa, glabra, de margem inteira. Fruto ca. 0,5 mm compr., ovóide, pseudo-pedicelado, pouco imerso na raque quando maduro, deixando perceptível a pseudocúpula basal nítida, disposta até a porção mediana, ápice agudo; estigma apical.

Distribuição geográfica e habitat: Brasil, em Minas Gerais, Rio de Janeiro, São Paulo e em todos os estados da Região Sul. No estado do Rio de Janeiro ocorre apenas nos Parques Nacionais da Serra dos Orgãos e do Itatiaia, onde foi encontrada na floresta ombrófila densa montana e nos campos de altitude, entre 1.100 e $2.600 \mathrm{~m}$.

Material examinado: Maromba, 1.000 ms.m., II.1942, fl., A.C. Brade 17186 (RB); estrada nova $\mathrm{km} \mathrm{8,}$ 21.II.1948, fl. e fr., A. C. Brade 18886 (RB); planalto, proximidades do Brejo da Lapa, $22^{\circ} 15^{\prime} 28^{\prime \prime} \mathrm{S}$ 443'ㄴ'4"W, 2.100 ms.m., 3.XII.1996, fl., J. M. A. Braga et al. 3707 (RB); próximo à ponte do Maromba, 2.XII.2006, fl., D. Monteiro \& A.C. Giannerine 220 (RB).

Peperomia trineura é reconhecida pela filotaxia verticilada, tamanho e forma das folhas. Variações no tamanho e forma da lâmina foliar, por vezes em um mesmo espécime, aproxima o táxon de $P$. trineuroides, o que pode causar dúvida na identificação, como observado por Yuncker (1974). Entretanto, $P$. trineura apresenta-se menos robusta e com folhas mais estreitas e menores. Guimarães et al. (1985) observaram tricomas na face dorsal da lâmina, o que também não foi visto nos espécimes do Parna do Itatiaia. $\mathrm{O}$ nome do táxon está relacionado às três nervuras primárias das folhas. Floresce e frutifica de dezembro a fevereiro.

29. Peperomia trineuroides Dahlst., Kongl Svenska Vetensk. Acad. Handl. 33(2): 198, tab. 8, fig 2. 1900.

Fig. $7 \mathrm{~g}$

Erva $20-30 \mathrm{~cm}$ alt., rupícula, ereta, semiciófila; ramos crassos, cilíndricos, com nós vináceos, anguloso-sulcados quando secos, esparso-hirtelo a glabros. Folhas 4-7 verticiladas; pecíolo 2-5 $\mathrm{mm}$ compr., canaliculado, minutamente hirtelo a glabrescente; lâmina $1,2-2 \times 0,8-1,5 \mathrm{~cm}$, rômbico-lanceolada, rômbico-obovada, base aguda, atenuada, ápice contraído, agudo a obtuso, às vezes cerdoso ou esparsamente hirtelo na metade superior, não emarginado, crassa a papirácea quando seca, ligeiramente discolor, nítida na face adaxial, densa a moderadamente impressoglandulosa na face abaxial, glabra em ambas as faces, margem revoluta, eciliada; padrão de nervação misto, acródromo basal, broquidódromo; nervuras 3, impressas na face adaxial. Espigas $7-14 \times 0,1-0,2 \mathrm{~cm}$, terminais, solitárias, flexuosas, verde-claras; pedúnculo 1,5-2 cm compr., 


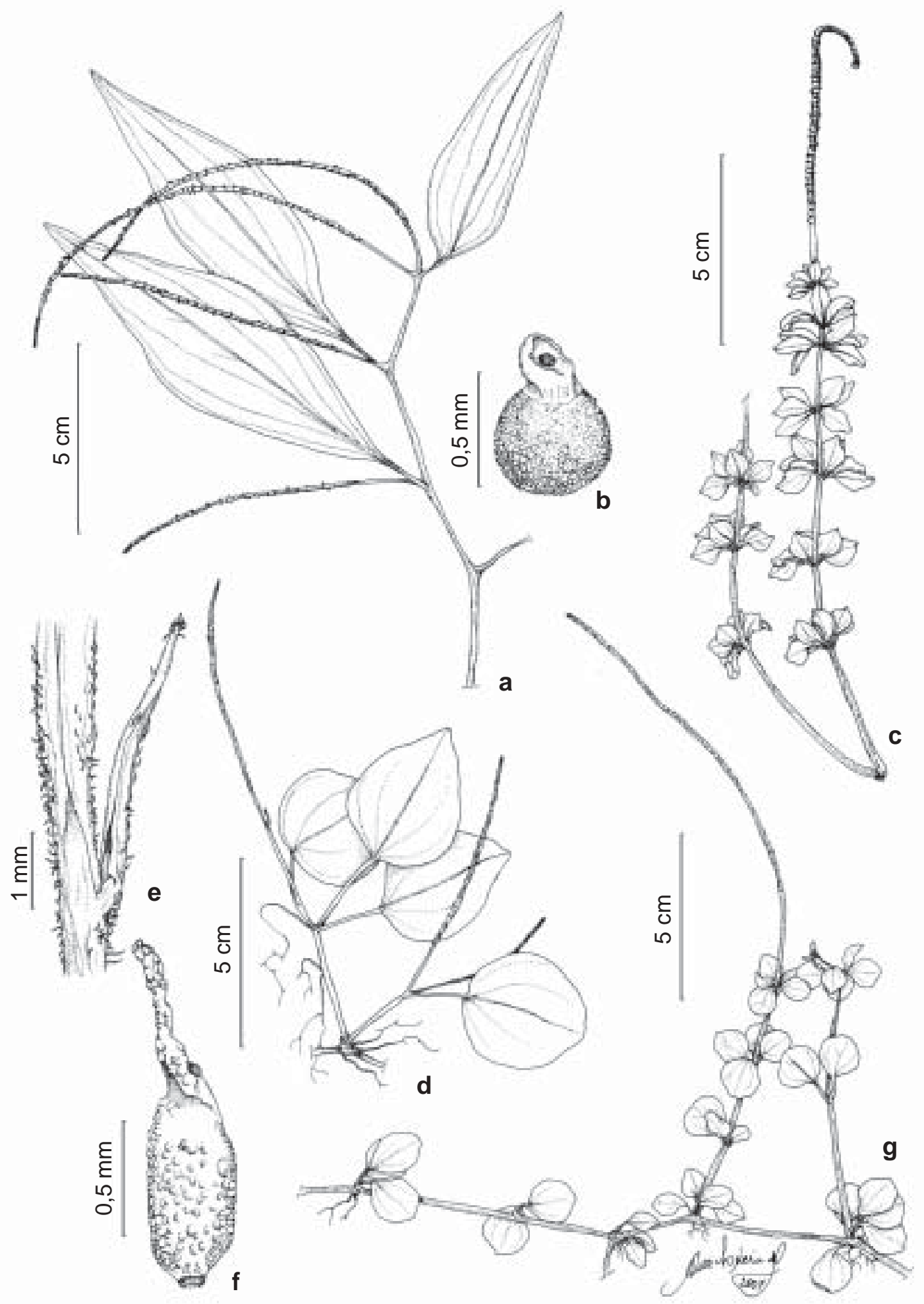

Figura 7 - a-b. Peperomia velloziana Miq. - a. hábito; b. fruto. c. P. trineura Miq. - c. hábito. d-f. P. urocarpa - d. hábito; e. bráctea peduncular; f. fruto. g. P. trineuroides Dahlst. - g. hábito. (a-b Monteiro 152; c Pereira 8; d-f Monteiro 123; g Monteiro 109). 
glabro; raque verrucosa, foveolada, glabra; flores densamente dispostas; bractéola arredondado-peltada, glandulosa, glabra, de margem inteira. Fruto ca. 1 mm compr., ovóide, ápice agudo, pouco imerso na raque, deixando nítida a pseudocúpula basal, disposta até a porção mediana, pseudo-pedicelado, vermelhoacastanhado; estigma apical.

Distribuição geográfica e habitat: Brasil, no Rio de Janeiro, São Paulo, Minas Gerais e em todos os estados da Região Sul. No estado do Rio de Janeiro ocorre apenas nos Parques Nacionais da Serra dos Órgãos e do Itatiaia, onde foi encontrada nos campos de altitude, entre 2.300 e $2.700 \mathrm{~m}$.

Material selecionado: rochedos da Serra do Itatiaia, 2.300 ms.m., III.1894, fl., E. Ule 277 (RB); Retiro, 13.V.1902, fl., P. Dusén s.n. (R-39.060); planalto, próximo ao cume das Prateleiras, 2.500 ms.m., 10.III.2005, fl. e fr., D. Monteiro et al. 109 (RB, S); Agulhas Negras, 2.700 ms.m., em pequeno fragmento na subida para o pico, 8.VIII.2006, fl., J. P. S. Condack \& D. Monteiro 518 (RB).

Material adicional examinado: RIO GRANDE DO SUL: Santo Angelo, 4.II.1893, fl., G. O. A. Malme 538 (Sintipo S, foto apud Yuncker 1974).

Peperomia trineuroides é reconhecida pela forma, filotaxia e tamanho das folhas. Yuncker (1974) encontrou variações no tamanho das folhas, freqüientemente no mesmo ramo, porém manteve $P$. trineuroides como espécie distinta (sensu Dahlstedt 1900). O autor comparou a espécie a $P$. trineura diferindo pelas folhas largas, espigas mais longas e por ser mais robusta. A diferenciação morfológica entre estas espécies é pouco consistente e por esta razão estão sendo desenvolvidos estudos mais acurados. O nome do táxon está relacionado às três nervuras primárias das folhas e à semelhança com $P$. trineura. Coletada com flor em março, maio e agosto e com fruto em março.

30. Peperomia urocarpa Fisch. \& C.A. Mey., Index Sem. (St. Petersburg) 4: 42, n. 1577. 1838.

Fig. 7d-f

Erva 12-20 cm alt., epífita ou rupícola, estolonífera, reptante, semi-umbrófila, vilosa, tricomas ca. 0,5 mm compr.; ramos ascendentes, carnosos, cilíndricos, densamente vilosos. Folhas alternas; pecíolo 1,5-3,5 (-4) cm compr., canaliculado, moderada a densamente viloso, tricomas mais concentrados no ápice; lâmina 3-5 ×2,5-4 cm, ovada, base obtusa, arredondada a cordada, ápice agudo, suculenta, papirácea quando seca, discolor, nítida na adaxial, vilosa em ambas as faces, tricomas moderadamente dispostos na face adaxial e esparsamente dispostos ao longo das nervuras da face abaxial, margem plana, ciliada; padrão de nervação misto, acródromo basal, camptódromo; nervuras 5 . Espigas (2,5-) 4,5-5,5 ×0,1 cm, eretas, 1-2, terminais ou opostas às folhas; pedúnculo 2,3$4 \mathrm{~cm}$ compr., moderada a densamente viloso; bráctea peduncular ca. 4,5 mm compr., falcadolanceolada, moderadamente glandulosa, esparsamente vilosa, cerdosa no ápice; raque foveolada, lisa, glabra; flores densamente dispostas; bractéola ovado-arredondada, glandulosa, glabra, de margem inteira. Fruto ca. 1,5 mm compr, elíptico, ápice rostrado, marromacastanhado, glanduloso, glabro, pouco imerso na raque quando maduro; estigma apical, na base do rostro.

Distribuição geográfica e habitat: Porto Rico, República Dominicana, México, América Central, Colômbia, Venezuela, Equador, Peru, Paraguai, Uruguai e Argentina. No Brasil ocorre no Rio Grande do Norte, Bahia, Brasília e em todos os estados das Regiões Sudeste e Sul. Apresenta vasta e expressiva dispersão por toda a faixa de floresta ombrófila densa do Parna do Itataiaia.

Material selecionado: Monte Serrat, 23.VII.1902, fl., P. Dusén 774 (R); estrada do Maromba, km 2,5, 6.X.1945, fl., A. Barbosa \& W. Barbosa 92 (RB); rio Taquaral, 7.X.1945, fl., A. Barbosa \& W. Barbosa 88 (RB, RFA); Donati, 20.IV.1962, fl., A. Castellanos 23956 (RB, GUA); trilha para os Três Picos, 22²5'88"S 44³6'41"W, 1.210 ms.m., 10.VIII.2004, fl., D. Monteiro et al. 72 (RB); atrás do alojamemto 3, em trilha próxima ao rio, 4.VI.2005, fl. e fr., $D$. Monteiro \& G. Santos 114 (RB, SP); trilha atrás do abrigo 4, próximo a cachoeira, 4.VI.2005, fl. e fr., $D$. Monteiro \& G. Santos 123 (RB, S); trilha na margem do Lago Azul, 17.III.2005, fl. e fr., D. Monteiro et al. 150 (RB, BHCB); trilha do Hotel Simon, 1.000 ms.m., 19.III.2005, fl. e fr., D. Monteiro et al. 168 (RB). 
Peperomia urocarpa é de fácil reconhecimento no Parna do Itatiaia, sendo os caracteres diagnósticos o hábito reptante, as lâminas ovadas e os frutos elípticos com ápice rostrado. Segundo Trelease \& Yuncker (1950) a espécie se assemelha de P. serpens (Sw.) Loudon, diferindo pelas folhas mais largas e as longas espigas. Apesar de Yuncker (1974) comentar sobre 1-2 brácteas pedunculares, apenas uma foi vista nos materiais do Parna do Itatiaia, assim como observado por Carvalho-Silva \& Cavalcanti (2002). O nome do táxon deriva da palavra grega uro (rabo, cauda) e carpo (frutos), como referência à forma alongada do ápice dos frutos. Floresce e frutifica de março a outubro.

31. Peperomia velloziana Miq., Syst. Piperac. 1: 88. 1843.

Fig. 7a-b

Erva $20-35 \mathrm{~cm}$ alt., epífita ou rupícula, umbrófila, glabra; ramos eretos ou decumbentes, estoloníferos, cilíndricos, suculentos, não alados, ligeiramente sulcados quando secos. Folhas alternas; pecíolo 6-13 mm compr., canaliculado, sem linha de tricomas; lâmina 7-11,5×2-3,4 cm, rômbeo-lanceolada, elíptico-lanceolada, base aguda, cuneada, decurrente, não peltada, ápice agudo, acuminado, não emarginado, cartácea a translúcido-membranácea quando seca, discolor, esparso-glandulosa na face abaxial, margem plana, eciliada; padrão de nervação misto, acródromo supra-basal, camptódromo; nervuras 6-8. Espigas 6,5-13 $\times 0,1 \mathrm{~cm}$, axilares ou terminais, 1-2, eretas, verde-claras; pedúnculo $0,8-2 \mathrm{~cm}$ compr.; raque lisa, foveolada; flores densamente dispostas; bractéola arredondado-peltada, esparsamente castanho glandulosa, de margem inteira. Fruto ca. $1 \mathrm{~mm}$ compr., globoso-ovóide, ápice com escudo oblíquo, densamente glanduloso, pouco imerso na raque, por vezes dorsalmente; estigma subapical.

Distribuição geográfica e habitat: Brasil, em Goiás, Bahia, Distrito Federal, Paraná e todos os estados da Região Sudeste. No Rio de
Janeiro é registrada apenas para os Parques Nacionais da Serra dos Órgãos e do Itatiaia, onde ocorre de forma pouco freqüente na floresta ombrófila densa montana.

Material selecionado: Maromba, 1.100 ms.m., 4.III.1962, fl. e fr., E. Pereira et al. 6989 (HB); estrada para o Lago Azul, 17.III.2006, fl. e fr., D. Monteiro et al. 152 (RB, SP); estrada para o Véu de Noiva; ca. 1.100 ms.m., 19.III.2006, fl. e fr., D. Monteiro et al. 169 (RB); trilha para a cachoeira do Itaporoni, 2.XII.2006, fl., D. Monteiro \& A. C. Giannerine 211 (RB).

Material adicional examinado: BRASIL. sem localidade, s.d., fl., F. Sellow s.n. (Isótipo K - foto apud Yuncker 1974).

Peperomia velloziana é reconhecida pelos ramos decumbentes, folhas rômbeolanceoladas, elíptico-lanceoladas com padrão de venação misto acródromo supra-basal, camptódromo e espigas longas, sendo bastante ornamental. Carvalho-Silva \& Cavalcanti (2002) descrevem o padrão de nervação como hifódromo e observaram frutos com forma ovado-elíptica, sementes rugosas e duas brácteas pedunculares opostas, na base do pedúnculo, de 2-3 mm compr., eretas e glabras com ápice obtuso. $\mathrm{Na}$ área de estudo, a espécie foi recoletada após 34 anos. O nome do táxon foi dado em homenagem a Vellozo. Floresce e frutifica de dezembro a março.

\section{Agradecimentos}

A Coordenação de Aperfeiçoamento de Pessoal de Nível Superior - CAPES e ao Conselho Nacional de Desenvolvimento Científico e Tecnológico - CNPq pelas bolsas concedidas. À Escola Nacional de Botânica Tropical, ao Programa Mata Atlântica/ Petrobrás e ao Parque Nacional de Itatiaia pela infra-estrutura. Aos curadores dos herbários consultados. Aos pesquisadores $\mathrm{Dr}^{\mathrm{a}}$ Andréa Ferreira da Costa, Dr ${ }^{\mathrm{a}}$ Rafaela Campostrini Forzza e Dr. Vidal de Freitas Mansano pelas sugestões e participação como membros da banca examinadora. A todos os amigos que contribuíram para a realização deste trabalho e a ilustradora botânica Ana Lúcia de Souza. 


\section{REFERÊNCIAS BIBLIOGRÁFICAS}

Barros, W. D. 1955. Parque Nacional do Itatiaia. Serviço de Informação Agrícola, Rio de Janeiro, 67p.

Bornstein, A.J. 1989. Taxonomic studies in the Piperaceae - I. The pedicellate pipers of México and Central América (Piper subg. Arctottonia). Journal of the Arnold Arboretum 70(1): 1-55.

Brade, A. C. 1956. A Flora do Parque Nacional do Itatiaia. Boletim $\mathrm{n}^{\circ}$ 5. Ministério da Agricultura, Serviço Florestal, 137p.

Burger, W. C. 1971. Piperaceae. In: Burger, W. (ed.). Flora Costaricensis. Fieldiana: Botany 35: 5-227.

Carvalho-Silva, M. \& Cavalcanti, T. B. 2002. Piperaceae. In: Cavalcanti, T. B. \& Ramos, A. E. (org.). Flora do Distrito Federal 2: 93-124.

Corrêa, M. P. 1984. Dicionário das Plantas Úteis do Brasil e das Exóticas cultivadas. Vol. 5. Ministerio da Agricultura, Instituto Brasileiro de Desenvolvimento Florestal, Rio de Janeiro.

Dahlstedt, H. 1900. Studien uber Sud-und Central-Amerikanische Peperomien. Kungl. Svenska. Vetenskaps Akademiens Handlingar 33(2): 1-218.

Dusén, P. K. H. 1905. Sur la Flore de la Serrra do Itatiaya. Arquivos do Museu Nacional, Rio de Janeiro 13: 1-120.

Guimarães, E. F.; Ichaso, C. L. F. \& Costa, C. G. 1984. Piperaceae. 4. Peperomia. In: Reitz, R. (ed.). Flora Ilustrada Catarinense. Itajaí, 112p.

Guimarães, E. F.; Ichaso, C. L. F. \& Mautone, L. 1985. Peperomia Ruiz e Pav. do Parque Nacional da Serra dos Órgãos, Bol. Mus. Bot. Kuhlmann 8(2):15-50.

Guimarães, E. F. \& Giordano, L. C. S. 2004. Piperaceae do Nordeste Brasileiro I: estado do Ceará. Rodriguésia 55(84): 21-46.

Hickey, L. J. 1974. Clasificacion de la arquitectura de las hojas de dicotiledoneas. Boletin de la Sociedad Argentina de Botanica 16(1-2): 1-26.
Hickey, M; \& King, C. 2003. The Cambridge Ilustrated Glossary of Botanical Terms. Cambridge University Press, New York, 208p.

Howard, R. A. 1973. Notes on the Piperaceae of the Lesser Antilles. Journal of the Arnold Arboretum 54: 377-411.

Ichaso, C. L. F. \& Guimarães, E. F. 1984. Piperaceae do Município do Rio de Janeiro - II. Peperomia Ruiz \& Pavon. Rodriguesia 36 (59): 47-60.

Jaramillo, M. A.; Manos, P. S. \& Zimmer, E. A. 2004. Phylogenetic relationships of the perianthless Piperales: reconstructing the evolution of floral development. International Journal of Plant Sciences 165(3): 403-416.

Langfield, R. D.; Scarano, F .J.; Heitzman, M. E.; Kondo, M.; Hammond, G. B. \& Neto, C. C. 2004. Use of a modified microplate bioassay method to investigate antibacterial activity in the Peruvian medicinal plant Peperomia galioides. Journal of Ethnopharmacology 94: 279-281.

Lorenzi, H. \& Matos, F. J. A. 2002. Plantas Medicinais no Brasil: nativas e exóticas. Instituto Plantarum, 512p.

Martinelli, G. 1989. Campos de Altitude-High Altitude Fields. Index, Rio de Janeiro, $152 \mathrm{p}$.

Medeiros, E. S. 2006. Flora do Parque Estadual de Ibitipoca, Minas Gerais, Brasil - Família Piperaceae. Dissertação de Mestrado. Instituto de Pesquisas Jardim Botânico do Rio de Janeiro/Escola Nacional de Botânica Tropical, 127p.

Milliken, W. 1997. Plants for Malaria, Plants for Fever: Medicinal species in Latin America - a bibliographic survey. The Royal Botanic Gardens, 116p.

Miquel, F. A. G. 1871. Enumeratio Piperacearum. In: Baumhaer, E. H. von. (ed.). Archives Neerlandeises des sciences exactes et naturalles 6: 168-176.

Parque Nacional do Itatiaia. Disponível em: http://www.ibama.gov.br/parna_itatiaia/. Acesso em: 2006. 
Ribeiro, K. T. \& Medina, B. M. O. 2002. Boletim do Parque Nacional do Itatiaia $\mathrm{n}^{\circ} 10$ Estrutura, Dinâmica e Biogeografia das Ilhas de Vegetação sobre Rocha do Planalto do Itatiaia. Itatiaia, RJ. Parque Nacional do Itatiaia/Universidade Federal Rural do Rio de Janeiro, 84p.

Rizzini, C. T. 1960. Sistematização terminológica da folha. Rodriguésia 23-24(35-36): 193-203.

1978. Latim para biologistas. Academia Brasileira de Ciências, 203p.

Rizzini, C. T. \& Rizzini, C. M. 1983. Dicionário botânico clássico latino-português abonado. Jardim Botânico do Rio de Janeiro, IBDF, 282p.

Trelease, W. 1936. Piperaceae. In: Macbride, J. F. (ed.). Flora of Peru. Field museum of natural history Botanical series 13(2): 3-253.

Trelease, W. \& Yuncker, T. G. 1950. The Piperaceae of Northern South América. University of Illinois Press, Urbana, 837p.

\section{ÍNDICE DE COLETORES}

Alves662 (10). Araújo 2044(10); 1706 (20). Barbosa 90 (7);91(11a);82 (12); 85(14); 89(16);80(17); 86(18); 83 (22); 81 (22); 87 (24); 84 (27); 88, 92 (30). Bautista 290 180 (10). Brade 18827, s.n. - HB 10277 (2); 17436, s.n. RB-69192(3); 14635,20192(4); 10248(6); 18814, 18818, 20238 (7); 17470 (8); 17437, 20237, 20239(10); 18815 (11a); 10501,14665, 17309, 20186(14); 14634(15); 10330 (17); 18859 (20); s.n. - pró-parte R- 22722 (25); s.n HB-10276 (26b); s.n. - HB-10278 (26c); 17186, 18886 (28). Braga 2002, 2285, 2421, 2802, 2938, (1); 1560,3725 (2); 2616, 2801 (7); 1943, 3213 (10); 2618 (12); 1352, 3804 (16); 1391, 2608, 2531 (17); 1327, 3724(18); 2434 (21); 2973 (22); 3805 (24); 3806 (25); 2834 (26c); 1625 (26b); 3707 (28); 2860 (29). Braga 2447 (10). Câmara 11685 (20); 11688 (24); s.n. - RB-197154(31). Carauta 362(14). Castellanos 23329(12); 23102(13); 23956(30). Carvalho-Silva 292 (11). Condack 460 (8); 518 (29). Duarte 861,(10); 875 (14). Dusén 761 (9); 667 (10); 760 (11); s.n. - R-39.060 (29); 774 (30). Ferreira 125 (11a); 225 (26c); 567 (27). Freitas 923 (10). Gardner 119/2 (7). Gaudichaud 282 (5). Giordano 793 (6); 796 (17); 794 (18). Glaziou 8942 (8). Guedes 2463 (2); 2499 (4); 2458 , 2480(6); 2545 (17); 2479 (26c). Kaempfes.n. - RB 87282 (29). Kuhlmann s.n. - SP 40200 (7); s.n. - RB 21190 (26c). Landrum 2137 (26c). Lima 334, 335 (6). Maas
Veloso, H. P.; Rangel Filho, A. L. R. \& Lima, J. C. A. 1991. Classificação da vegetação brasileira, adaptada a um sistema universal. IBGE - Departamento de Recursos Naturais e Estudos Ambientais, 123p.

Wanke, S.; Samain, M.S.; Vanderschaeva, L.; Mathieu, G.; Goetghebeur, P. \& Neinhuis, C. 2006. Phylogeny of the genus Peperomia (Piperaceae) inferred from the trnk/matk region (cpDNA). Plant Biology 8: 93-102.

Yuncker, T.G. 1950. Piperaceae. In: Woodson, R. E. \& Schery, R. W. (eds.) Flora of Panama, Annals of the Missouri Botanical Garden 37 (1): 1-120. 1953. The Piperaceae of Argentina, Bolivia and Chile. Lilloa 27: 8-303. 1958. The Piperaceae - A family profile. Brittonia 10: 1-7. 1974. The Piperaceae of Brazil III Peperomia; Taxa of uncertain status. Hoehnea 4: 71-413.

3218(20). Malme 522(9); 206(18); 538(29). Marinho 166(1). Marquete4069b, 4069c (18). Martinelli 1078, 3250 (1); 1598, 9244 (4); 1604, 1614 (10); 11633 (23); 10780 (30). Martins 105(10). Martius s.n. (16). Mattos 20362 (RB). Melo s.n. - RB 148591(12). Monteiro 113 $138(1) ; 62,68,90,209,231(2) ; 128,130,148,170(3)$; $115,116,147,149(4) ; 56(5) ; 57,63,64,67,74,89,91$, 100; 101, 134(7); 65, 194, 230(8); 78, 107, 127, 183(10); 215, 218 (11); 157 (11a); 76, 97, 98, 103, 105, 133, 135 (13); 60, 75, 81, 92, 96, 104, 118(14); 73, 119, $153(17)$; 121, 125(19); 70, 88, 93, 236(18); 79, 129(21);214(22); 166(23); 198, 200, 238(24); 126, 132(25); 197, 237(26b); 66, 83, 195, 196, 217 (26c); 212 (27); 220 (28); 109, 172 (29); 72, 114, 123, 150, 168 (30); 169, 152, 211 (31). Monteiro s.n. - RBR 16.189 (4); 18/62 (11a). Mosén 2568 (7). Occhioni s.n. - RFA4383, 7095, 8687 (10); s.n. -RFA 4380 (14). Pastore 634 (23). Peixoto 690 (24). Pereira 5709, 6990(10); 6988(13);6989(31). Pereira 8 (28). Porto 739 (6). Ramos 26 (26c). Ribeiro s.n. RFA28799(10). Rossi 1594(8). Ruiz s.n. (27). Sampaio 4163 (9). Schenck 1017 (7). Segadas-Vianna s.n. RFA 22869 (10); s.n. - RFA 22871 (21). Sellow s.n. (13); s.n. (31). Silva Neto 882 (2); 898 (7). Strang 339, 795, 962 (10); 963 (31). Sucre 4644 (10). Sylvestre 1832 (26c). Ule 276 (10); 8590 (19); 277 (29). Yepes s.n. - RB 435413 (26a). 